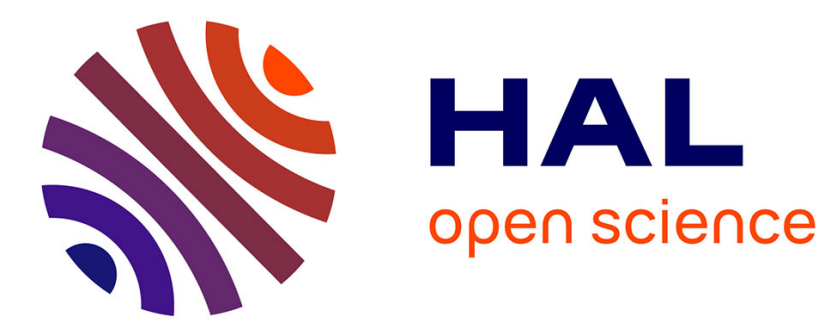

\title{
Trophic ecology drives trace element concentrations in the Antarctic octopod community
}

\author{
Alexandra Lischka, Paco Bustamante, H. Braid, Uwe Piatkowski, T. \\ Lacoue-Labarthe
}

\section{- To cite this version:}

Alexandra Lischka, Paco Bustamante, H. Braid, Uwe Piatkowski, T. Lacoue-Labarthe. Trophic ecology drives trace element concentrations in the Antarctic octopod community. Science of the Total Environment, 2021, 768, pp.144373. 10.1016/j.scitotenv.2020.144373 . hal-03126737

\section{HAL Id: hal-03126737 \\ https://hal.science/hal-03126737}

Submitted on 1 Feb 2021

HAL is a multi-disciplinary open access archive for the deposit and dissemination of scientific research documents, whether they are published or not. The documents may come from teaching and research institutions in France or abroad, or from public or private research centers.
L'archive ouverte pluridisciplinaire HAL, est destinée au dépôt et à la diffusion de documents scientifiques de niveau recherche, publiés ou non, émanant des établissements d'enseignement et de recherche français ou étrangers, des laboratoires publics ou privés. 
Trophic ecology drives trace element concentrations in the Antarctic octopod community

\begin{abstract}
A. Lischka ${ }^{1 *}$, P. Bustamante ${ }^{2,3}$ H. Braid ${ }^{1}$, U. Piatkowski ${ }^{4}$, T. Lacoue-Labarthe ${ }^{2}$
\end{abstract}
${ }^{1}$ AUT Lab for Cephalopod Ecology \& Systematics, School of Science, Auckland University of Technology, Private Bag 92006, 1142, Auckland, New Zealand

${ }^{2}$ Littoral Environnement et Sociétés (LIENSs), UMR 7266 CNRS-La Rochelle Université, 2 rue Olympe de Gouges, 17000 La Rochelle, France

${ }^{3}$ Institut Universitaire de France (IUF), 1 rue Descartes 75005 Paris, France

${ }^{4}$ GEOMAR, Helmholtz Centre for Ocean Research Kiel, Düsternbrooker Weg 20, 24105 Kiel, Germany

*corresponding author: alexandralischka90@ gmail.com 


\begin{abstract}
Despite the Antarctic Ocean being considered a pristine environment, elevated trace element concentrations have been reported in many marine organisms. The Antarctic Ocean is particularly vulnerable to climate change, which can also affect the bioaccumulation of trace element concentrations in biota. While Antarctic octopods are key components of the regional food webs as prey for a variety of predators (e.g., seals, fish, and seabirds), their contamination state by trace elements remains largely unknown. This study investigated the trace element concentrations in relation to the trophic ecology in Antarctic octopods. Stable isotope values $\left(\delta^{13} \mathrm{C}\right.$ and $\left.\delta^{15} \mathrm{~N}\right)$ and trace element concentrations (Ag, As, $\mathrm{Cd}, \mathrm{Co}, \mathrm{Cr}, \mathrm{Cu}, \mathrm{Fe}, \mathrm{Hg}, \mathrm{Mn}, \mathrm{Ni}, \mathrm{Pb}$, $\mathrm{Se}, \mathrm{V}$, and $\mathrm{Zn}$ ) were measured in eight different species (Adelieledone polymorpha, Pareledone aequipapillae, P. albimaculata, P. aurata, P. charcoti, P. cornuta, P. felix, and P. turqueti) sampled near Elephant Island, close to the Antarctic Peninsula. Stable isotopes of $\delta^{15} \mathrm{~N}$ varied among species, with significant differences between $A$. polymorpha and P. aurata suggesting potential niche segregation. Trace element concentrations also differed among species and with sampling depth, which likely reflects their trophic ecology. The data presented in this study provides the first insight into the trace element concentrations for these endemic octopods in this vulnerable habitat and their stable isotope values.
\end{abstract}

Keywords: Cephalopods, Cd, Hg, Southern Ocean, Antarctica, Stable Isotopes 


\section{Introduction}

Antarctica is recognized for its stable environment, sheltering numerous endemic species, and unique geography, which makes it especially susceptible to climate change as highlighted by increasing temperatures (Gille, 2002) and $\mathrm{CO}_{2}$ saturation (Le Quéré et al., 2007). It is the southernmost continent and contains $90 \%$ of Earth's ice masses, which make up about $70 \%$ of Earth's freshwater reservoir (Bentley and Giovinetto, 1992). The surrounding Antarctic Ocean plays a crucial role in Earth's oceanic circulation by connecting three main oceans - the Atlantic, Indian, and Pacific Oceans - and contains up to $6 \%$ of the world's oceanic volume (Eakins and Sharman, 2010). In addition, the high levels of atmospheric transport and the connectivity of ocean currents make the Antarctic Ocean susceptible to inorganic pollutants (Potapowicz et al., 2019). Elevated concentrations of trace elements (in particular $\mathrm{Cd}$ and $\mathrm{Hg}$ ) have been reported in Antarctic crustaceans (Keil et al., 2008; Petri and Zauke, 1993), fish (Bargagli et al., 2000; Bustamante et al., 2003; Goutte et al., 2015), seabirds (Blévin et al., 2013; Carravieri et al., 2013, 2014), and marine mammals (Andrade et al., 2007; Honda et al., 1987). For Subantarctic and Antarctic cephalopods, some studies demonstrated moderate $\mathrm{Hg}$ levels and very high Cd concentrations (Bustamante et al., 1998b; Matias et al., 2019; Trevizani et al., 2018; Seco et al., 2020). Global cephalopod studies have demonstrated their remarkable bioaccumulation potential for trace elements, such as $\mathrm{Ag}, \mathrm{Cd}$, and $\mathrm{Hg}$ (Bustamante et al., 2006; Martin and Flegal 1975; Miramand and Bentley 1992). Although the trace element concentrations in benthic octopods from temperate waters have been previously studied (e.g., Chouvelon et al., 2011; Raimundo et al., 2005; Rjeibi et al., 2014), comparative data from the Southern Ocean is lacking for most benthic octopods. 
Cephalopods are key components of the Antarctic ecosystem (Collins and Rodhouse, 2006; Xavier et al., 2018). Benthic octopods have a role as both predator and prey, and are crucial in the transfer of energy and trace elements in the Antarctic food web, linking low trophic level consumers to high-level predators (Allcock,1997; 2005; Allcock et al., 2001; Daly, 1996; Piatkowski et al., 1998; 2003; Strugnell et al., 2017). A wide variety of predators feed on benthic octopods, for example: elephant seals (Mirounga leonine, Burdman et al., 2015; Daneri et al., 2000; Rodhouse et al., 1992), Weddell seals (Leptonychotes weddellii, Acevedo et al., 2015; Casaux et al., 1997; Lipinski and Woyciechowski, 1981; Negri et al., 2016), Patagonian toothfish (Dissostichus eleginoides, Xavier et al., 2002), and the black-browed albatross (Thalassarche melanophris, Xavier and Croxall, 2007). In turn, benthic octopods prey on crustaceans, polychaetes, bivalves, gastropods (Daly, 1996), and amphipods (Daneri et al., 2000; Piatkowski et al., 2003). Clear differences in the feeding ecology among octopod species were proposed based on the interspecific variation observed in beak morphology (Matias et al. 2019, Schwarz et al., 2019) and stomach content analyses (Büring, 2019; Daly, 1996; Piatkowski et al., 2003). These differences suggest that Antarctic benthic octopods occupy different trophic niches, despite their geographic co-occurrence.

The purpose of the present study is to investigate the role that the eight benthic octopod species, collected from near Elephant Island, might play in the transfer of trace elements in this pristine Antarctic ecosystem. We tested two hypotheses: 1) we expect to see differences between individuals of different sizes, due to ontogenetic shifts in feeding, as well as between the mantle and digestive gland tissues, the two main storage organs for trace elements in cephalopods. Furthermore, the relative trophic position of each octopod species (assessed through the $\delta^{15} \mathrm{~N}$ in mantle as a proxy) and their feeding habitat $\left(\delta^{13} \mathrm{C}\right.$ in mantle) should differ at the intraspecific and interspecific levels; and 2) we expect to see niche partitioning reflected by interspecific 
differences in the stable isotope values. The trophic ecology is supposed to mainly drive the trace element contamination differences recorded in individuals' tissues.

\section{Material and Methods}

\section{Sample collection}

Specimens were collected during a research cruise of the German research vessel 'Polarstern' (ANT-XXVIII/4) in March/April 2012 near Elephant Island, South Shetland Islands (Lucassen, 2012). The sampling area ranged from $61^{\circ} 04^{\prime}$ to $61^{\circ} 37^{\prime} \mathrm{S}$ and $54^{\circ} 88$ to $56^{\circ} 17^{\prime} \mathrm{W}$. Samples were caught in depths of 109-323 m by bottom otter trawling (OTB, Fig. 1; Table 1). A total of 60 individuals from eight different species (Table 1) were subsampled from approximately 800 collected specimens in total (Lucassen, 2012). For each specimen, the sampling depth (m), the mantle and total length (mm), and the sex (male, female, or sex unknown [indet./juvenile]) was noted. Specimens were stored at $-40^{\circ} \mathrm{C}$ until they were analyzed for trace elements, stable isotopes, and genetics.

\section{Species identification}

Specimens were initially morphologically identified to species level on board of the research vessel, and identification were verified genetically for specimens that could not be confidently identified to species. When an identification was uncertain, a tissue snip was taken from the arm and stored frozen for later DNA analysis. DNA was extracted using EconoSpin columns (Epoch Life Science) with QIAGEN reagents, following protocols for the DNeasy Blood \& Tissue Kit (QIAGEN). The mitochondrial gene cytochrome $c$ oxidase subunit I (COI), was amplified using primers and protocols following Braid et al. (2014). The sequence reaction was performed using the primer $\mathrm{HCO} 2198$, which was the reverse primer used for the PCR 
(Macrogen, Korea). Sequences were edited in CodonCode Aligner (CodonCode Corp., Dedham, MA, USA) and uploaded to the Barcode of Life Data System (Ratnasingham and Hebert, 2007) and subsequently submitted to GenBank. All sequences were screened for potential contamination using GenBank's Basic Local Alignment Search Tool (BLAST). Genetic identifications were made using the Full Database identification engine on BOLD.

\section{Stable isotope analysis}

Carbon and nitrogen stable isotopes were measured from freeze-dried tissue samples $(0.2-0.4$ mg) with a continuous flow mass spectrometer (Delta V Plus with a Conflo IV interface, Thermo Scientific, Bremen, Germany) coupled to an elemental analyser (Flash 2000, Thermo Scientific, Milan, Italy) following Lischka et al. (2018). Stable isotope values were calculated using the following formula: $\delta^{13} \mathrm{C}$ or $\delta^{15} \mathrm{~N}=\left[\left(\mathrm{R}_{\text {sample }} / \mathrm{R}_{\text {standard }}\right)-1\right] \times 10^{3}$, where $\mathrm{R}$ is ${ }^{13} \mathrm{C} /{ }^{12} \mathrm{C}$ or ${ }^{15} \mathrm{~N} /{ }^{14} \mathrm{~N}$; all results are expressed in the \%o unit notation as a deviation of the standard (Vienna Pee Dee Belemnite for $\delta^{13} \mathrm{C}$ and $\mathrm{N}_{2}$ in air for $\delta^{15} \mathrm{~N}$ ). Internal laboratory standards (acetanilide and peptone) were used to assess the analytical precision, which was $<0.10 \%$ for $\delta^{13} \mathrm{C}$ and $<0.15 \%$ for $\delta^{15} \mathrm{~N}$.

\section{Trace element analysis}

Digestive gland and mantle tissue samples were freeze-dried for 48-72 hours and ground into a homogenous powder. The water content in the octopod species (measured in P. charcoti, as an example) was $68 \pm 8 \%$ in the digestive gland, and $79 \pm 3 \%$ in the mantle tissue. Sample aliquots were prepared with $\sim 200 \mathrm{mg}$ dry weight (dw) of the tissue samples and digested overnight in a 3:1 mixture of $65 \% \mathrm{HNO}_{3}$ (Merck, suprapur quality) and $37 \% \mathrm{HCl}$ (Merck, suprapur quality). The acidic digestion was followed by a mineralization, where samples were heated for $30 \mathrm{~min}$ in a Milestone microwave (maximum temperature of $105^{\circ} \mathrm{C}$ ). Trace element 
concentrations (Ag, As, Cd, Co, Cr, $\mathrm{Cu}, \mathrm{Fe}, \mathrm{Mn}, \mathrm{Ni}, \mathrm{Pb}, \mathrm{Se}, \mathrm{V}$, and $\mathrm{Zn}$ ) were measured by inductively coupled plasma mass spectroscopy (ICP-MS) — with a Thermo Fisher Scientific X Series 2 - and by optical emission spectroscopy (ICP-OES) — with a Varian Vista-Pro ICPfollowing Lucia et al. (2016). Dogfish liver (DOLT-4, National Research Council, Canada), lobster hepatopancreas (TORT-3, NRCC), and clam muscle tissue (IAEA-461, International Atomic Energy Agency, Austria) were used as certified reference materials (CRMs). CRMs, together with procedural blanks, were treated and analyzed in the same way as the samples. Recoveries of the elements ranged from $85-105 \%(n=9)$. The detection limits for Ag, Cd, Co, $\mathrm{Cr}$, and $\mathrm{Pb}$ were $0.025 \mu \mathrm{g} \mathrm{g}^{-1}$, Ni was $0.05 \mu \mathrm{g} \mathrm{g}^{-1}, \mathrm{Cu}, \mathrm{Mn}$, and Se were $0.125 \mu \mathrm{g} \mathrm{g}^{-1}$, As was $0.25 \mu \mathrm{g} \mathrm{g}^{-1}, \mathrm{~V}$ was $0.5 \mu \mathrm{g} \mathrm{g}^{-1}$, and Fe and $\mathrm{Zn}$ were $5 \mu \mathrm{g} \mathrm{g}^{-1}$, and based on $200 \mathrm{mg}$ of sample material diluted in a volume of $50 \mathrm{ml}$. The Cd concentrations was only measured in the octopod digestive gland tissue and not in the mantle tissue due to a potential diffusion effect (Francesconi et al., 1993; Lischka et al., 2020a).

Sample aliquots (1-2 mg) of the dried homogenized digestive gland and mantle tissue were used to analyse $\mathrm{Hg}$ using an Advanced Mercury Analyser (ALTEC AMA 254, with a detection limit $>0.05 \mathrm{ng}$ ) as described in Bustamante et al. (2006). For every 10 samples, one standard sample of certified reference material DOLT 5 (Dogfish liver; NRCC) was analyzed with a recovery of $109 \pm 2 \%$. Results for all trace element concentrations are expressed in $\mu \mathrm{g} \mathrm{g}^{-1} \mathrm{dw}$.

\section{Statistical analyses}

All statistical analyses were conducted with the statistical software R (R Core Team, 2017; Ihaka and Gentleman, 1996). The species Pareledone felix $(n=2)$ and P. turqueti $(n=1)$ were excluded from all statistical analysis and the interspecific comparisons due to their small sample sizes. 
Analysis of covariance (ANCOVA) was performed on log-standardised $\delta^{15} \mathrm{~N}$ and $\delta^{13} \mathrm{C}$ values to check if these were influenced by size (total length), sampling depth, sex (female, sex unknown [indet./ juvenile], male), and species.

Interspecific differences in stable isotope values were assessed with Tukey's post-hoc tests ('glht' function, R package 'multcomp', Hothorn et al., 2016). Adjustment of the $p$-values was conducted following Benjamini and Hochberg (1995).

A principal component analysis (PCA) was applied as an exploratory tool to examine differences in overall trace element concentrations among species for the digestive gland tissue. Prior to the PCA, data was normalised and z-transformed (auto-scaled, mean centred, and divided by the standard deviation).

To test whether tissue type, sampling depth, species, size (as total length), "sex", $\delta^{15} \mathrm{~N}$ and the residuals of $\delta^{13} \mathrm{C}$ had an influence on trace element concentrations, generalised linear models (GLMs) with a negative binomial distribution and logit link function were applied (GLM, package 'MASS', Ripley et al., 2013). The fit of the models was confirmed by analysing the residuals. One model per trace element was fitted against non-transformed concentrations and the variables were added sequentially. Since the variables $\delta^{13} \mathrm{C}$ and $\delta^{15} \mathrm{~N}$ were correlated (Pearson's $r=0.71$ ), only the residuals of the correlation between $\delta^{13} \mathrm{C}$ and $\delta^{15} \mathrm{~N}$ were included in the models. Because size is affected by species, these variables were included as an interaction term in the models.

ANCOVAs were performed to see whether "sex", size, and/or stable isotopes had an influence on trace element concentrations for $P$. charcoti, because this species had a balanced sample size (11 females, 11 males). This model was chosen because the residuals of the $P$. charcoti dataset were normally distributed. 


\section{Results}

Species identifications

Sixty specimens were morphologically identified to the species level (Adelieledone polymorpha, Pareledone aequipapillae, P. albimaculata, $P$. aurata, $P$. charcoti, $P$. cornuta, Pareledone felix, and P. turqueti; Table 1). Among them, the identification of 14 specimens were confirmed with DNA barcoding, confirming a total of eight species (99.83-100\% match in the BOLD database). The morphological species identification (size variations, Fig. 2) suggests that $P$. aurata and $P$. albimaculata might include more species than confirmed with DNA barcoding.

\section{Stable isotopes}

The $\delta^{13} \mathrm{C}$ and $\delta^{15} \mathrm{~N}$ values varied significantly among the species (ANCOVA, $p<0.001$; Table 2), indicating that the foraging habitats and diets differ among subantarctic octopods. On average, the highest $\delta^{13} \mathrm{C}$ values were measured in A. polymorpha, $P$. aequipapillae, $P$. felix and $P$. turqueti, whereas $P$. albimaculata, $P$. charcoti and $P$. cornuta had similar (or overlapping) values, and P. aurata showed lowest $\delta^{13} \mathrm{C}$ values (Fig. 3; Table S1). Statistically, only the $\delta^{13} \mathrm{C}$ values of $A$. polymorpha and P. aurata differed significantly in the Tukey's posthoc tests $(p<0.001)$. In addition, sex had a significant effect on $\delta^{13} \mathrm{C}$ (Table 2), with males and juveniles exhibiting the highest values $(p<0.05$, Table 2$)$. Regarding the $\delta^{15} \mathrm{~N}$ values, $A$. polymorpha exhibited the highest average value (Table S1), followed by $P$. aequipapillae, $P$. albimaculata, P. felix, and P. turqueti (Fig. 3). Lower average $\delta^{15} \mathrm{~N}$ values were measured in $P$. cornuta, but the lowest $\delta^{15} \mathrm{~N}$ values were recorded in 29 individuals of $P$. aurata and $P$. charcoti (which differed significantly from all other species; Tukey's post hoc test, $p<0.001$ ). Both $\delta^{13} \mathrm{C}$ and $\delta^{15} \mathrm{~N}$ values are positively correlated (Pearson's $r=0.71 ; \mathrm{p}<0.05$ ) indicating that the highest $\delta^{13} \mathrm{C}$ values were measured in specimens with the highest $\delta^{15} \mathrm{~N}$ values (Table 2). In 
addition, sampling depth had a significant effect on $\delta^{13} \mathrm{C}$ and $\delta^{15} \mathrm{~N}$ values (Table 2), with the lowest $\delta^{13} \mathrm{C}$ values and the highest $\delta^{15} \mathrm{~N}$ values measured in specimens sampled in deeper waters.

\section{Trace elements}

Average trace elements in the digestive gland were measured in decreasing order as follows: $\mathrm{Fe}>\mathrm{Cu}>\mathrm{Zn}>\mathrm{Cd}>\mathrm{V}>\mathrm{As}>\mathrm{Ag}>\mathrm{Se}>\mathrm{Co}>\mathrm{Mn}>\mathrm{Ni}>\mathrm{Pb}>\mathrm{Cr}>\mathrm{Hg}$ (Table $\mathrm{S} 1)$. In the mantle tissue, the average trace element concentrations decreased as follows: $\mathrm{Zn}>\mathrm{Cu}>\mathrm{As}>\mathrm{Fe}>\mathrm{Se}>$ $\mathrm{V}>\mathrm{Mn}>\mathrm{Ni}>\mathrm{Ag}>\mathrm{Co}>\mathrm{Hg}>\mathrm{Cr}>\mathrm{Pb}$ (Table $\mathrm{S} 1)$.

The PCA of the digestive gland tissue showed that Principal Component (PC) 1 explained $38.6 \%$ of the variance and was mainly driven by $\mathrm{Ag}, \mathrm{Cd}, \mathrm{Co}, \mathrm{Cu}, \mathrm{Fe}, \mathrm{Hg}$, and $\mathrm{Pb}$, whereas $\mathrm{PC} 2$ explained $18.1 \%$ of the variance and was mainly driven by As, Cr, Mn, Ni, Se, and V (Fig. 4). The specimens of $P$. charcoti formed a distinct cluster along the $\mathrm{PC} 1$ influenced by highest $\mathrm{Ag}$, $\mathrm{Cd}, \mathrm{Co}, \mathrm{Cu}, \mathrm{Pb}$, and $\mathrm{Zn}$ concentrations recorded in this species (see Table $\mathrm{S} 1$ ). The samples of A. polymorpha, A. aequipapillae and A. albimaculata formed a distinct group, characterised by higher $\mathrm{As}, \mathrm{Cr}$, and $\mathrm{Ni}$ concentrations. Overall, $P$. albimaculata displayed the highest concentrations of As and V (also supported by the GLMs, Table 3), P. aequipapillae the highest ones of $\mathrm{Cr}, \mathrm{Fe}, \mathrm{Hg}$, and $\mathrm{Mn}$ (not confirmed by the GLMs), and A. polymorpha the highest $\mathrm{Ni}$ and Se concentrations (Table S1; supported by the GLMs, Table 3).

The GLMs analyses confirmed that the concentrations of $\mathrm{As}, \mathrm{Cd}, \mathrm{Co}, \mathrm{Fe}, \mathrm{Ni}, \mathrm{Pb}, \mathrm{Se}, \mathrm{V}$, and $\mathrm{Zn}$ significantly differed among species (Table 3) and that all concentrations, with the exception of As and $\mathrm{Hg}$, are higher in the digestive gland compared to the mantle tissue. Arsenic tended to be more concentrated in the muscle than in the digestive gland in all species, whereas the Hg concentrations remained similar between the two tissues (Table S1). Sex had an impact on 
$\mathrm{Cd}, \mathrm{Co}, \mathrm{Cu}, \mathrm{Fe}$, and $\mathrm{Pb}$ concentrations in both tissues, with juveniles (sex indet.) and males generally exhibiting higher concentrations relative to females (Table 3, Fig. S1). Finally, the concentrations of $\mathrm{Cu}$ (Fig. S2) and Zn decreased significantly with increasing size, while Se significantly increased with size (Table 3).

The stable isotope values of $\delta^{15} \mathrm{~N}$ had a significant positive effect on $\mathrm{Ag}$, As, and $\mathrm{Se}$ concentrations and a significant negative effect on Cd concentrations (Table 3). None of the analyzed variables had an effect on $\mathrm{Hg}$ concentrations. The residuals of $\delta^{13} \mathrm{C}$ did not show a significant effect on any of the analyzed trace elements.

Sampling depth had a significant effect on $\mathrm{Co}, \mathrm{Fe}, \mathrm{Ni}, \mathrm{Pb}, \mathrm{Se}$, and V concentrations (Table 3), which were highest in specimens sampled in shallower waters. In contrast, As concentrations reached the highest concentrations in individuals collected in deeper waters (Table 3).

\section{Pareledone charcoti}

Focusing on the sample set of $P$. charcoti ( $n=11$ males and 11 females), the concentrations of $\mathrm{Ag}, \mathrm{Co}, \mathrm{Cr}, \mathrm{Cu}, \mathrm{Fe}, \mathrm{Ni}, \mathrm{Pb}, \mathrm{Se}, \mathrm{V}$, and $\mathrm{Zn}$ differed significantly between digestive gland and mantle tissue, with highest concentrations measured in the digestive gland (Table S2). Significantly higher concentrations of $\mathrm{Cd}, \mathrm{Co}, \mathrm{Cr}, \mathrm{Cu}, \mathrm{Fe}, \mathrm{Ni}, \mathrm{Pb}, \mathrm{Se}$, and $\mathrm{Zn}$ were also measured in males (Table S2; Fig. S2) compared to females. The concentrations of $\mathrm{Hg}$ and Zn increased with increasing $\delta^{15} \mathrm{~N}$ values ( $p<0.05$; Table S2).

\section{Discussion}

Although cephalopods, particularly benthic octopods, are a key component of the Antarctic food web, little is known about their trophic ecology in the Southern Ocean (Seco et al., 2020). In this study, we report the stable isotope values and the concentrations of 14 trace elements in eight different octopod species sampled near Elephant Island. For the first time, stable isotopes and trace elements are linked together to describe niche segregation by feeding and habitat 
tracers, in these endemic octopod species. Our study demonstrated that shallower living octopods are distinguished from deeper living species by their habitat and diet, and that reflected on their isotopic signature and trace elemental burden. This clear segregation may have ecological repercussions for predators that feed on different species or that hunt at different depths.

\section{Trophic ecology}

The $\delta^{15} \mathrm{~N}$ signature is a reliable indicator of the trophic position in specific food webs (Cherel et al., 2009; Richert et al., 2015). A relative comparison of this proxy among the species the Antarctic and Subantarctic octopus assemblages investigated here reveals that Paraeledone aurata and $P$. charcoti are distinguished from the other species by their low $\delta^{15} \mathrm{~N}$ values (Fig. 3), suggesting a lower trophic position. These results are consistent with those from a recent study on the feeding ecology of Antarctic octopods from the same area, which reported higher $\delta^{15} \mathrm{~N}$ values in A. polymorpha and $P$. aequipapillae relative to $P$. charcoti (Büring, 2019). These differences were linked to their stomach content analysis, which revealed that octopods living at greater depths (e.g. A. polymorpha) consumed prey at higher trophic levels, such as fish. In contrast, species living in shallower waters, such as $P$. charcoti, base their diet on crustaceans and amphipods (Piatkowski et al., 2003). In line with this observation, our specimens of $P$. aurata and $P$. charcoti were collected at depths ranging from 109 to $178 \mathrm{~m}$, whereas individuals from the other analyzed species were sampled below $288 \mathrm{~m}$ depth. The significant effect of sampling depth found in the ANCOVAs (Table 2) may indicate a spatial segregation of the octopod species with depth, probably driving a contrasting feeding ecology between A. polymorpha and $P$. aurata, reflected by the significant difference in $\delta^{15} \mathrm{~N}$ values (Table S1). 
The carbon stable isotope signature can be used to assess habitat differences between species, since $\delta^{13} \mathrm{C}$ values exhibit a latitudinal gradient, with highest values measured inshore relative to offshore habitats, and higher values in benthic species relative to pelagic species (Cherel et al. 2009; Chouvelon et al., 2011). Most of the species analyzed herein (i.e., P. aequipapillae, P. albimaculata, P. charcoti, $P$. charcoti, $P$. felix and $P$. turqueti) displayed a narrow range in $\delta^{13} \mathrm{C}$ values (from -25.42 to -24.09 ), suggesting that they share an overlapping feeding habitat. No significant effect of $\delta^{13} \mathrm{C}$ values independently of the $\delta^{15} \mathrm{~N}$ values was measured in this study, likely due to the small $\delta^{13} \mathrm{C}$ values variation, which never exceeded $2 \%$ (Table S1).

\section{Arsenic}

Most trace element concentrations in the digestive gland were generally higher than the mantle tissue, which is consistent with the detoxification and storage role of the digestive gland usually recognized in cephalopods, including octopods (e.g., Miramand and Bentley, 1992; Bustamante et al., 1998b; Miramand et al., 2006; Seixas et al., 2005). However, As concentrations were higher in the mantle tissue than in the digestive gland (Table S1). This could reflect the affinity of arsenobetaine, the major As species in cephalopods (Taylor et al., 2017) to the proteins in the muscular tissue (Shen et al., 2013). This has been already described in other cephalopods, such as nautilus, Nautilus macromphalus (Bustamante et al., 2000), and arrow squid, Nototodarus sloanii (Lischka et al., 2020a).

Some trace elements are not well documented in cephalopods (e.g., Ag, As, and V), which makes the interpretation for those elements challenging. Nevertheless, As concentration data is available for certain cephalopod species (e.g., Todarodes filippovae, Kojadinovic et al., 2011). The As concentrations measured in all octopods in this study were higher (digestive 
gland As concentration average $=37.48 \mu \mathrm{g} \mathrm{g}^{-1} \mathrm{dw}$ ) relative to pelagic squid species from previous studies (e.g., Gonatus fabricii, $10.18 \mu \mathrm{g} \mathrm{g}^{-1} \mathrm{dw}$, Lischka et al., 2020b; Sthenoteuthis pteropus, $18.33 \mu \mathrm{g} \mathrm{g}^{-1} \mathrm{dw}$, Lischka et al., 2018), but comparable to octopod species from temperate environments (e.g., Octopus vulgaris; $40 \mu \mathrm{g} \mathrm{g}^{-1} \mathrm{dw}$, Raimundo et al., 2010). This is congruent with the well-supported hypothesis that the benthic $v s$ pelagic habitat is the main driver of As accumulation since As tends to be trapped in sediments (Sanders, 1980). In the present study, the deeper living $P$. albimaculata and $P$. polymorpha had the highest concentrations of As among the eight studied octopod species (Table S1; Fig. 4). Cephalopods mainly accumulate As through their diet (Kojadinovic et al. 2011), and since information about the feeding ecology of this species is currently not available, conclusions between diet and As exposure cannot be drawn. However, our results show that sampling depth and $\delta^{15} \mathrm{~N}$ values both positively influenced As concentrations (Table 3) likely reflecting that feeding at higher trophic levels results in higher As contamination. This may suggest a higher As bioavailability in octopod prey with depth and/or the biomagnification of the organic As compounds between prey and octopods (Kubota et al., 2001; Neff, 1997; Tu et al., 2011). Further dietary studies are needed to confirm this hypothesis.

\section{Cadmium}

The variations in Cd concentrations have been described for cephalopod species from different oceanic origins (Table 4). It is noteworthy that the Antarctic octopods in the present study display similar Cd concentrations with temperate species, such as Octopus vulgaris from the Mediterranean Sea (Miramand and Guary, 1980) and Eledone cirrhosa from the English Channel (Miramand and Bentley, 1992). However, the latter species displayed a higher variation in Cd concentrations with respect to its location when compared to E. cirrhosa from the Bay of Biscay (Chouvelon et al., 2011) and from the Faroe Islands (Bustamante et al., 
1998a), which displayed at least 50\% lower and 1800\% higher Cd concentrations, respectively, compared to the A. polymorpha samples (Table 4). In contrast, it could be hypothesized that the reason that benthic octopods show lower levels of $\mathrm{Cd}$ within the pan-Antarctic region is due to the more homogenous and stable environment that characterizes this area.

The Cd concentrations measured in this study were relatively high and similar to concentrations from urbanized coasts (Table 4). This could be because of an enrichment of $\mathrm{Cd}$ in the surface layers due to upwelling events (Bustamante et al., 1998b). It could also be due to the limited bioavailability of essential elements such as $\mathrm{Cu}$ and $\mathrm{Zn}$, leading to an enhanced uptake of $\mathrm{Cd}$ (Gault-Ringold et al., 2012; Petri and Zauke, 1993). Therefore, organisms may have developed very efficient mechanisms of elemental uptake for $\mathrm{Cu}$ and $\mathrm{Zn}$ (Petri and Zauke, 1993). Because these mechanisms are probably not specific to $\mathrm{Cu}$ and $\mathrm{Zn}, \mathrm{Cd}$ might be absorbed by the same physiological pathways (Penicaud et al., 2017). These high Cd concentrations might also be attributable to the ' $\mathrm{Cd}$ anomaly', which describes a latitudinal gradient of $\mathrm{Cd}$ concentration in marine invertebrates (including octopods), where higher $\mathrm{Cd}$ concentrations have been measured in marine organisms from subpolar areas. These descriptions include amphipods (Bargagli et al., 1996; Kahle and Zauke, 2002; Petri and Zauke, 1993), fish (Bustamante et al. 2003; Macdonald and Sprague 1988; Zauke et al. 1999), and cephalopods (Bustamante et al. 1998a, Cipro et al. 2017).

There is a general paucity of data concerning trace elements in Antarctic octopods, but the high Cd concentrations in the digestive gland in Graneledone gonzalezi and Benthoctopus thielei from the subantarctic Kerguelen Islands (Bustamante et al., 1998b) are within the same range of the present values, suggesting that the Cd anomaly may occur in the South Shetland Islands area.

This study further reported significant differences in Cd concentration data among different species (GLMs; Table 3), with $P$. charcoti and $P$. aurata displaying the highest Cd 
concentrations (see also Fig. 4). These results suggest that $\mathrm{Cd}$ concentration differences, consistent with the $\delta^{15} \mathrm{~N}$ signature (Table 3), can be used to highlight the diet partitioning of octopod species. For example, $P$. charcoti has shown high Cd levels and their diet includes $\mathrm{Cd}$ richer prey (amphipods, crustaceans; Büring, 2019), while A. polymorpha showed lower Cd levels and is known to consume prey of higher trophic levels (e.g., fish; Büring, 2019) with lower Cd concentrations (Storelli and Marcotrigiano, 2004). Our results suggest that Cd concentration data might be used to discriminate and characterise the ecological niche of octopod species.

Apart from interspecific differences, significant differences in $\mathrm{Cd}$ concentrations were observed between the sexes in the GLMs, with the highest concentrations measured in male $P$. charcoti specimens relative to females of the same species (Table 3, Fig. S1). Paraledone charcoti was the only species in the present study that had a balanced sample set (11 females and 11 males), which was the reason other species could not be evaluated this way. Since cephalopods mainly take up Cd though their diet (Bustamante et al., 2002; Koyama et al. 2000), this difference could be due to diet composition, highlighting a niche partitioning between sexes (Table 3). Such a difference in diet between sexes was previously reported for $O$. mimus from Northern Chilean waters, with females having a higher food intake relative to males (Cortez et al., 1995). Therefore, the amount of ingested prey but also their type should also influence Cd concentrations. In this respect, $P$. charcoti females might ingest more Cd-poor prey compared to males. To confirm sex differences in the diet of Antarctic benthic octopods, additional stomach content analysis, both morphologically and genetically, is necessary. 


\section{Mercury}

The concentration of $\mathrm{Hg}$ measured in the mantle muscles of $P$. turqueti from the South Georgia coast was similar to the $\mathrm{Hg}$ concentrations measured in the present study (Matias el al., 2019; 2020). Worldwide, $\mathrm{Hg}$ concentrations fluctuated among octopod species and sampling locations, with the highest concentrations measured in E. cirrhosa from the Tyrrhenian Sea (Rossi et al. 1993; Barghigiani et al 2000). The Hg concentrations in the present study were similar to those reported for $O$. vulgaris from the Portuguese Coast (Seixas et al., 2005), and E. cirrhosa, from the Bay of Biscay (Chouvelon et al., 2011; Table 4). Benthic species in the Octopodidae usually display higher $\mathrm{Hg}$ concentrations compared to other cephalopod families (Penicaud et al., 2017). The specimens analyzed in the present study showed lower $\mathrm{Hg}$ concentrations relative to pelagic Antarctic squids; for example, $\mathrm{Hg}$ concentrations measured in the digestive gland of the squid Kondakovia longimana $\left(0.045 \pm 0.021 \mu \mathrm{g} \mathrm{g}^{-1} \mathrm{dw}\right.$; Seco et al., 2020) were ten-fold lower when compared to A. polymorpha (Table 4). This highlights the interspecific as well as inter-location variability of $\mathrm{Hg}$ concentrations. Surprisingly, none of the proxies of trophic and habitat ecology have an effect on $\mathrm{Hg}$ concentrations among species, whereas $\mathrm{Hg}$ levels usually increases with benthic habitat and trophic position (Chouvelon et al., 2012). This result is likely related to the close ecological niches shared by Antarctic octopods and indicate that $\mathrm{Hg}$ would be a pertinent proxy for the trophic position and the habitat (benthic/pelagic) at the cephalopod assemblage scale (i.e., including benthic octopods and pelagic squids) in future comparative ecological studies (e.g., Seco et al., 2020).

\section{Lead}

Lead is one of the major pollutants in oceanic systems (Boyle et al., 2014). In the present study, $\mathrm{Pb}$ concentrations in the digestive gland varied among species, with $P$. charcoti exhibiting significantly higher concentrations compared to the other species analyzed (Fig. S1). This finding is consistent with a previous study on Antarctic benthic invertebrate communities, 
which also showed significant variations of $\mathrm{Pb}$ concentrations among species (Majer et al., 2014). This variation was attributed to the anthropogenic pollution in the Admiralty Bay at King George Island. However, because Elephant Island is a near-pristine ecosystem, it is unlikely that $\mathrm{Pb}$ has reached high levels due to anthropogenic causes. Instead, the shallowliving $P$. charcoti might be exposed to higher $\mathrm{Pb}$ concentrations due to diet, since it mainly feeds on invertebrates (Büring, 2019), which are known to bioaccumulate this element (Rainbow, 1997). Feeding at higher trophic levels should reduce the exposure to this element because it is bioreduced along the food webs (Michaels and Flegal, 1990). Furthermore, higher $\mathrm{Pb}$ concentrations are associated with near-surface water layers (Henderson and Maier-Reimer, 2002). The reasons for oceanic depth differences are not yet fully understood, and anthropogenic sources - e.g., aeolian dust from industrial applications—were described as a major contributor (Rosman et al., 1994; Sun and Xie, 2001). Although Pb concentrations in deeper waters of the Antarctic region of the Indian Ocean have increased over the last century, they are still lower when compared with oceanic regions that have higher regional anthropogenic emissions and slower vertical mixing rates (Echegoyen et al., 2014). Apart from the interspecific concentration differences found in the present study, $\mathrm{Pb}$ was generally higher in males and juveniles relative to females (Table 3, Fig. S1). A similar pattern has been observed in the squid Gonatus fabricii (from the Arctic ocean; Lischka et al., 2020b) and in $O$. vulgaris (from the Mediterranean Sea; Rjeibi et al., 2014), where Pb concentrations in the digestive gland were lowest in females and associated with feeding habits. An analysis of sexspecific dietary patterns is needed in order to make further conclusions about the effects of sex on $\mathrm{Pb}$ bioaccumulation. 


\section{Potential impacts on ecosystem}

The shallower-living species $P$. charcoti had significantly higher concentrations of $\mathrm{Ag}, \mathrm{Cd}, \mathrm{Co}$, $\mathrm{Cu}, \mathrm{Pb}$, and $\mathrm{Zn}$, compared to all other species analyzed in the present study (Fig. 4). These elevated concentrations could be related to the diet of $P$. charcoti, which is known to consist mainly of crustaceans (particularly amphipods; Piatkowski et al., 2003; Büring, 2019). In contrast, the larger A. polymorpha has a diet that contains fish, which generally exhibit lower trace element concentrations (particularly, the non-essential elements $\mathrm{Ag}, \mathrm{Cd}$, and $\mathrm{Pb}$ ) than crustaceans (Chouvelon et al., 2011; Pierce et al., 2008). Since diet can be considered a major source for trace element exposure (Bustamante et al., 1998a), the measured differences in trace element concentrations among species in this study are likely due to differences in feeding habits and rates. One of the main findings of this study is the significant difference in $\delta^{15} \mathrm{~N}$ values found in $P$. charcoti and $P$. aurata (relative to all other analyzed species, which is supported by ecological tracers (trace elements, isotopic signature). In addition, based on the ranges of the $\delta^{15} \mathrm{~N}$ values and the significant effect of depth on $\delta^{15} \mathrm{~N}$ values (Table 2), the analyzed Antarctic octopod community seems to be a widely unique group with two segregated species, $P$. charcoti and $P$. aurata. This might likely reflect distinct ecological niches, driven by depth and leading to different diets. However, considering the narrow range of $\delta^{13} \mathrm{C}$ variation among all species, the feeding patterns of the octopods investigated in our study do not seem differently enough to emphasize contrasted foraging habitats.

The species assessed in this study are consumed by a variety of Antarctic top predators (see Introduction; e.g., Casaux et al., 1997; Daneri et al., 2000; Lipinski and Woyciechowski, 1981; Rodhouse et al., 1992; Xavier et al., 2002), which are exposed to trace elements, sometimes in elevated concentrations, when they feed on the species analyzed in the present study. In particular, the high $\mathrm{Cd}$ concentrations measured in the digestive gland samples might represent 
a significant point source for predators (Bustamante et al. 2008). High Cd concentrations were measured in Antarctic seals and explained by dietary exposure, which includes benthic octopods, particularly the shallower $P$. charcoti, which exhibits the highest Cd concentrations found in the present study (Casaux et al., 1997; Malcolm et al., 1994; Szefer et al., 1994). Our study highlights that incirrate octopods represent a vector for trace elements, including $\mathrm{Cd}$ and $\mathrm{Hg}$, to top predators foraging near Antarctic Elephant Island. This has been previously shown for other oceanic areas (Bustamante et al., 1998a; Penicaud et al., 2017). Pinnipeds such as the Antarctic fur seal Arctocephalus gazella and the Southern elephant seal Mirounga leonina might be exposed to elevated trace element concentrations due to their octopod-rich diet (Burdman et al., 2015; Casaux et al., 1998). Consistently, elevated Cd concentrations have been measured in liver and kidney tissues of A. gazella, which were associated with hepatotoxicity and nephrotoxicity (De Moreno et al., 1997; Malcolm et al., 1994). Overall, the extent of the toxic effects of trace elements on both predators and prey still remains understudied. In this context, it is necessary to provide information to allow risk assessment evaluations.

\section{Conclusion}

In this study, stable isotopes $\left(\delta^{13} \mathrm{C}\right.$ and $\left.\delta^{15} \mathrm{~N}\right)$ and trace elements $(\mathrm{Ag}, \mathrm{As}, \mathrm{Cd}, \mathrm{Co}, \mathrm{Cr}, \mathrm{Cu}, \mathrm{Fe}$, $\mathrm{Hg}, \mathrm{Mn}, \mathrm{Ni}, \mathrm{Pb}, \mathrm{Se}, \mathrm{V}$, and $\mathrm{Zn}$ ) were assessed in an octopod assemblage collected near Elephant Island in the Antarctic Ocean. Significant differences were measured between sexes and species. For example, $P$. aurata and $P$. charcoti exhibited significantly lower $\delta^{15} \mathrm{~N}$ values compared to A. polymorpha, which indicates that they feed at a lower trophic level. This is consistent with the sampling depths of $P$. aurata and $P$. charcoti, which occurred in shallower waters than A. polymorpha. This suggests. a spatial segregation of the octopod species with depth, which could drive a contrasting feeding ecology. Furthermore, most trace element concentrations (with the exception of $\mathrm{Hg}$ ) varied between species, suggesting different 
bioaccumulation patterns, which likely reflect trophic habitat discrimination. Our results are consistent with the few previous dietary studies on these species and highlight the influence of benthic Antarctic octopods in the transfer of trace elements to their main predators, which is the first step in unravelling the complex interactions in this unique and irreplaceable environment.

\section{Acknowledgments}

We thank the crew of the RV Polarstern (ANT-XXVIII/4) for sampling these precious specimens. We would also like to thank Christoph Noever and Felix Mark for species collection and identification. AL would like to thank Veronique Merten and Stella Scheer for their amazing help in taking tissue samples. We would like to thank the Roche Lab and the Auckland University of Technology for financing the barcoding in this study. The authors are grateful to Carine Churlaud and Maud Brault-Favrou from the Plateforme Analyses Elémentaires of LIENSs for their support during the trace element analysis and to Gaël Guillou from the Plateforme Analyses Isotopiques of LIENSs for running the stable isotope analysis. Thanks are due to the CPER (Contrat de Projet Etat-Région) and the FEDER (Fonds Européen de Développement Régional) for funding the ICPs, the AMA, and the IRMS of LIENSs laboratory. The IUF (Institut Universitaire de France) is acknowledged for its support to PB as a Senior Member.

\section{References}

Acevedo, J., Carreno, E., Torres, D., Aguayo-Lobo, A., Letelier, S., 2015. Cephalopod remains in scats of Weddell seals (Leptonychotes weddellii) at Cape Shirreff, South Shetland Islands, Antarctica. Polar Biology, 38(9), 1559-1564.

Allcock, A.L., 1997. The genetics and taxonomy of Southern Ocean Octopodidae, with special reference to the genus Pareledone (PhD Thesis). University of Liverpool. 
Allcock, A.L., 2005. On the confusion surrounding Pareledone charcoti (Joubin, 1905) (Cephalopoda: Octopodidae): endemic radiation in the Southern Ocean. Zoological Journal of the Linnean Society 143, 75-108.

Allcock, A.L., Piatkowski, U., Rodhouse, P.G.K., Thorpe, J.P., 2001. A study on octopodids from the eastern Weddell Sea, Antarctica. Polar Biology 24, 832-838.

Andrade, S., Carlini, A.R., Vodopivez, C., Poljak, S., 2007. Heavy metals in molted fur of the southern elephant seal Mirounga leonina. Marine Pollution Bulletin 54, 602-605.

Bargagli, R., Nelli, L., Ancora, S., Focardi, S., 1996. Elevated cadmium accumulation in marine organisms from Terra Nova Bay (Antarctica). Polar Biology 16, 513-520.

Bargagli, R., Sanchez-Hernandez, J.C., Monaci, F., Focardi, S., 2000. Environmental factors promoting bioaccumulation of $\mathrm{Hg}$ and $\mathrm{Cd}$ in Antarctic marine and terrestrial organisms. Antarctic ecosystems: models for wider ecological understanding (ed. W. Davison, C. Howard-Williams, P. Broady) 308-314.

Barghigiani, C., Ristori, T., Biagi, F., De Ranieri, S., 2000. Size related mercury accumulations in edible marine species from an area of the Northern Tyrrhenian Sea. Water, Air, and Soil Pollution, 124(1-2), 169-176.

Benjamini, Y., Hochberg, Y., 1995. Controlling the false discovery rate: a practical and powerful approach to multiple testing. Journal of the Royal Statistical Society Series B, 57, 289-300.

Bentley, C.R., Giovinetto, M.B., 1992. Mass balance of Antarctica and sea level change. Wisconsin University, Madison Department of Geology, Geophysical and Polar Research Center, 8.

Blévin, P., Carravieri, A., Jaeger, A., Chastel, O., Bustamante, P., Cherel, Y., 2013. Wide range of mercury contamination in chicks of Southern Ocean seabirds. PLoS One 8, e54508.

Boyle, E.A., Lee, J.M., Echegoyen, Y., Noble, A., Moos, S., Carrasco, G., Zhao, N., Kayser, R., Zhang, J., Gamo, T., Obata, H., 2014. Anthropogenic lead emissions in the ocean: The evolving global experiment. Oceanography, 27(1), 69-75.

Braid, H.E., McBride, P.D., Bolstad, K.S., 2014. Molecular phylogenetic analysis of the squid family Mastigoteuthidae (Mollusca, Cephalopoda) based on three mitochondrial genes. Hydrobiologia, 725, 145-164.

Burdman, L., Daneri, G.A., Negrete, J., Mennucci, J.A., Marquez, M.E., 2015. Cephalopoda as prey of juvenile southern elephant seals at Isla 25 de Mayo/King George, South Shetland Islands. Iheringia. Série Zoologia, 105(1), 12-19.

Büring, T., 2019. Feeding ecology of Antarctic octopods (MSc thesis). University of Kiel. 
Bustamante, P., Bocher, P., Cherel, Y., Miramand, P., Caurant, F., 2003. Distribution of trace elements in the tissues of benthic and pelagic fish from the Kerguelen Islands. Science of the Total Environment 313, 25-39.

Bustamante, P., Caurant, F., Fowler, S.W., Miramand, P., 1998a. Cephalopods as a vector for the transfer of cadmium to top marine predators in the north-east Atlantic Ocean. Science of the Total Environment 220, 71-80.

Bustamante, P., Cherel, Y., Caurant, F., Miramand, P., 1998b. Cadmium, copper and zinc in octopuses from Kerguelen Islands, Southern Indian Ocean. Polar Biology 19, 264-271.

Bustamante, P., Grigioni, S., Boucher-Rodoni, R., Caurant, F., Miramand, P., 2000. Bioaccumulation of 12 trace elements in the tissues of the nautilus Nautilus macromphalus from New Caledonia. Marine Pollution Bulletin, 40(8), 688--96.

Bustamante, P., Lahaye, V., Durnez, C., Churlaud, C., Caurant, F., 2006. Total and organic Hg concentrations in cephalopods from the North Eastern Atlantic waters: influence of geographical origin and feeding ecology. Science of the Total environment 368, 585596.

Bustamante P., González A.F., Rocha F., Miramand P., Guerra A. (2008) Metal and metalloid concentrations in the giant squid Architeuthis dux from Iberian waters. Marine Environmental Research, 66(2), 278-287.

Bustamante, P., Teyssié, J.-L., Fowler, S.W., Cotret, O., Danis, B., Miramand, P., Warnau, M., 2002. Biokinetics of zinc and cadmium accumulation and depuration at different stages in the life cycle of the cuttlefish Sepia officinalis. Marine Ecology Progress Series 231, $167-177$.

Carravieri, A., Bustamante, P., Tartu, S., Meillère, A., Labadie, P., Budzinski, H., Peluhet, L., Barbraud, C., Weimerskirch, H., Chastel, O., Cherel, Y., 2014. Wandering albatrosses document latitudinal variations in the transfer of persistent organic pollutants and mercury to Southern Ocean predators. Environmental Science \& Technology 48 (24): 14746-14755. dx.doi.org/10.1021/es504601m.

Casaux, R., Baroni, A., Carlini, A., 1997. The diet of the Weddell seal Leptonychotes weddelli at Harmony Point, South Shetland Islands. Polar Biology 18, 371-375.

Casaux, R., Baroni, A., Carlini, A., 1998. The diet of the Antarctic fur seal Arctocephalus gazella at Harmony Point, Nelson Island, South Shetland Islands. Polar Biology, 20(6), $424-428$. 
Cherel, Y., Ridoux, V., Spitz, J. and Richard, P., 2009. Stable isotopes document the trophic structure of a deep-sea cephalopod assemblage including giant octopod and giant squid. Biology Letters, 5(3), 364-367.

Chouvelon, T., Spitz, J., Cherel, Y., Caurant, F., Sirmel, R., Mèndez Fernandez, P., Bustamante, P., 2011. Species and ontogenic-related differences in $\delta^{13} \mathrm{C}$ and $\delta^{15} \mathrm{~N}$ values and $\mathrm{Hg}$ and Cd concentrations of cephalopods. Marine Ecology Progress Series 433, 107-120.

Chouvelon, T., Spitz, J., Caurant, F., Mèndez-Fernandez, P., Autier, J., Lassus-Débat, A., Chappuis, A., Bustamante, P., 2012. Enhanced bioaccumulation of mercury in deep-sea fauna from the Bay of Biscay (north-east Atlantic) in relation to trophic positions identified by analysis of carbon and nitrogen stable isotopes. Deep Sea Research I 65, $113-124$.

Cipro, C.V., Cherel, Y., Bocher, P., Caurant, F., Miramand, P., Bustamante, P., 2018. Trace elements in invertebrates and fish from Kerguelen waters, southern Indian Ocean. Polar Biology, 41(1), 175-191.

Collins, M.A., Rodhouse, P.G., 2006. Southern Ocean cephalopods. Advances in Marine Biology, 50, 191-265.

Cortez, T., Castro, B.G., Guerra, A., 1995. Feeding dynamics of Octopus mimus (Mollusca: Cephalopoda) in northern Chile waters. Marine Biology 123, 497-503.

Daly, H.I., 1996. Ecology of the Antarctic octopus Pareledone from the Scotia Sea (PhD Thesis). University of Aberdeen.

Daneri, G.A., Carlini, A.R., Rodhouse, P.G.K., 2000. Cephalopod diet of the southern elephant seal, Mirounga leonina, at King George Island, South Shetland Islands. Antarctic Science 12, 16-19.

De Moreno, J.E.A., Gerpe, M.S., Moreno, V.J., Vodopivez, C., 1997. Heavy metals in Antarctic organisms. Polar Biology, 17(2), 131-140.

Eakins, B.W., Sharman, G.F., 2010. Volumes of the World's Oceans from ETOPO1. NOAA National Geophysical Data Center, Boulder, CO 7.

Echegoyen, Y., Boyle, E.A., Lee, J.M., Gamo, T., Obata, H., Norisuye, K., 2014. Recent distribution of lead in the Indian Ocean reflects the impact of regional emissions. Proceedings of the National Academy of Sciences, 111(43), 15328-15331.

Francesconi K.A., Moore, E.J., Joll, L.M., 1993. Cadmium in the saucer scallop, Amusium balloti, from western Australian waters: concentrations in adductor muscle and redistribution following frozen storage. Marine and Freshwater Research, 44(6), 787797. 
Gault-Ringold, M., Adu, T., Stirling, C.H., Frew, R.D., Hunter, K.A. (2012). Anomalous biogeochemical behavior of cadmium in subantarctic surface waters: mechanistic constraints from cadmium isotopes. Earth and Planetary Science Letters 341, 94-103.

Gille, S.T., 2002. Warming of the Southern Ocean since the 1950s. Science 295, 1275-1277.

Goutte, A., Cherel, Y., Churlaud, C., Ponthus, J.-P., Massé, G., Bustamante, P., 2015. Trace elements in Antarctic fish species and the influence of foraging habitats and dietary habits on mercury levels. Science of the Total Environment 538, 743-749.

Henderson, G.M. and Maier-Reimer, E., 2002. Advection and removal of ${ }^{210} \mathrm{~Pb}$ and stable $\mathrm{Pb}$ isotopes in the oceans: a general circulation model study. Geochimica et Cosmochimica Acta, 66(2), 257-272.

Honda, K., Yamamoto, Y., Kato, H., Tatsukawa, R., 1987. Heavy metal accumulations and their recent changes in southern minke whales Balaenoptera acutorostrata. Archives of Environmental Contamination and Toxicology 16, 209-216.

Hothorn, T., Bretz, F., Westfall, P., Heiberger, R.M., Schuetzenmeister, A., Scheibe, S., Hothorn, M.T., 2016. Package 'multcomp.' Simultaneous inference in general parametric models. Project for Statistical Computing, Vienna, Austria.

Ihaka, R., Gentleman, R., 1996. R: A language for data analysis and graphics. Journal of Computational and Graphical Statistics, 5, 299-314.

Kahle, J., Zauke, G.-P., 2002. Bioaccumulation of trace metals in the copepod Calanoides acutus from the Weddell Sea (Antarctica): comparison of two-compartment and hyperbolic toxicokinetic models. Aquatic Toxicology 59, 115-135.

Keil, S., De Broyer, C., Zauke, G.-P., 2008. Significance and interspecific variability of accumulated trace metal concentrations in Antarctic benthic crustaceans. International Review of Hydrobiology 93, 106-126.

Koyama, J., Nanamori, N., Segawa, S., 2000. Bioaccumulation of waterborne and dietary cadmium by oval squid, Sepioteuthis lessoniana, and its distribution among organs. Marine Pollution Bulletin, 40, 961-967.

Kojadinovic, J., Jackson, C.H., Cherel, Y., Jackson, G.D., Bustamante, P., 2011. Multielemental concentrations in the tissues of the oceanic squid Todarodes filippovae from Tasmania and the southern Indian Ocean. Ecotoxicology and Environmental Safety, 74, 1238-1249. https://doi.org/10.1016/j.ecoenv.2011.03.015

Kubota, R., Kunito, T., Tanabe, S., 2001. Arsenic accumulation in the liver tissue of marine mammals. Environmental Pollution 115, 303-312. 
Le Quéré, C., Rödenbeck, C., Buitenhuis, E.T., Conway, T.J., Langenfelds, R., Gomez, A., Labuschagne, C., Ramonet, M., Nakazawa, T., Metzl, N., 2007. Saturation of the Southern Ocean $\mathrm{CO}_{2}$ sink due to recent climate change. Science 316, 1735-1738.

Lipinski, M., Woyciechowski, M., 1981. Cephalopods in the food of Weddell seals from the Admiralty Bay (King George Island, South Shetland Islands). Polish Polar Research, 2(3-4), 163-167.

Lischka, A., Lacoue-Labarthe, T., Hoving, H.J.T., JavidPour, J., Pannell, J.L., Merten, V., Churlaud, C., Bustamante, P., 2018. High cadmium and mercury concentrations in the tissues of the orange-back flying squid, Sthenoteuthis pteropus, from the tropical Eastern Atlantic. Ecotoxicology and Environmental Safety, 163, 323-330. https://doi.org/10.1016/j.ecoenv.2018.07.087

Lischka, A., Pook, C.J., Pannell, J.L., Braid, H.E., Gaw, S., Bolstad, K.S., 2020a. Distribution of trace elements in the tissues of arrow squid (Nototodarus sloanii) from the Chatham Rise, New Zealand: Human health implications. Fisheries Research, 221, 105383.

Lischka, A., Lacoue-Labarthe, T., Bustamante, P., Piatkowski, U. and Hoving, H.J.T., 2020b. Trace element analysis reveals bioaccumulation in the squid Gonatus fabricii from polar regions of the Atlantic Ocean. Environmental Pollution, 256, 113389.

Lucassen, M., 2012. The expedition of the research vessel" Polarstern" to the Antarctic in 2012 (ANT-XXVIII/4). Berichte zur Polar-und Meeresforschung (Reports on Polar Research) 652.

Lucia, M., Strøm, H., Bustamante, P., Gabrielsen, G.W., 2016. Trace element concentrations in relation to the trophic behaviour of endangered Ivory Gulls (Pagophila eburnea) during their stay at a breeding site in Svalbard. Archives of Environmental Contamination and Toxicology 71, 518-529.

Macdonald, C.R., Sprague, J.B., 1988. Cadmium in marine invertebrates and arctic cod in the Canadian Arctic. Distribution and ecological implications. Marine Ecology Progress Series, 17-30.

Majer, A.P., Petti, M.A.V., Corbisier, T.N., Ribeiro, A.P., Theophilo, C.Y.S., de Lima Ferreira, P.A., Figueira, R.C.L., 2014. Bioaccumulation of potentially toxic trace elements in benthic organisms of Admiralty Bay (King George Island, Antarctica). Marine Pollution Bulletin 79, 321-325.

Malcolm, H.M., Boyd, I.L., Osborn, D., French, M.C., Freestone, P., 1994. Trace metals in Antarctic fur seal (Arctocephalus gazella) livers from Bird Island, South Georgia. Marine Pollution Bulletin 28, 375-380. 
Michaels, A.F., Flegal, A.R., 1990. Lead in marine planktonic organisms and pelagic food webs. Limnology and Oceanography, 35(2), 287-295.

Matias, R., Seco, J., Gregory, S., Belchier, M., Pereira, M.E., Bustamante, P., Xavier, J.C. (2020) Antarctic octopod beaks as proxy for mercury concentrations in soft tissues. Marine Pollution Bulletin, 158, 111447.

Matias, R.S., Gregory, S., Ceia, F.R., Baeta, A., Seco, J., Rocha, M.S., Fernandes, E.M., Reis, R.L., Silva, T.H., Pereira, E., Piatkowski, U., Ramos, J.A., Xavier, J.C., 2019. Show your beaks and we tell you what you eat: Different ecology in sympatric Antarctic benthic octopods under a climate change context. Marine Environmental Research 150, 104757.

Miramand, P., Bentley, D., 1992. Concentration and distribution of heavy metals in tissues of two cephalopods, Eledone cirrhosa and Sepia officinalis, from the French coast of the English Channel. Marine Biology 114, 407-414.

Miramand, P., Guary, J.-C., 1980. High concentrations of some heavy metals in tissues of mediterranean octopus. Bulletin of Environmental Contamination and Toxicology 24, 783-788.

Neff, J.M., 1997. Ecotoxicology of arsenic in the marine environment. Environmental Toxicology and Chemistry 16, 917-927.

Negri, A., Gustavo A.D., Ceia, F., Vieira, R., Cherel, Y., Coria, N.R., Corbalán, A., Xavier, J.C. (2016). The cephalopod prey of the Weddell seal, Leptonychotes weddellii, a biological sampler of the Antarctic marine ecosystem. Polar Biology 39(3), 561-564.

Penicaud, V., Lacoue-Labarthe, T., Bustamante, P., 2017. Metal bioaccumulation and detoxification processes in cephalopods: A review. Environmental Research 155, $123-$ 133. https://doi.org/10.1016/j.envres.2017.02.003

Petri, G., Zauke, G.-P., 1993. Trace metals in crustaceans in the Antarctic Ocean. Ambio-Journal of Human Environment Research and Management 22, 529-536.

Piatkowski, U., Allcock, A.L., Hevia, M., Steimer, S., Vecchione, M., 1998. Cephalopod ecology. In: Kattner, G. (ed.): The expedition ANTARKTIS XIV/2 of RV "Polarstern" in 1996/97. Berichte zur Polarforschung (Reports on Polar Research) 274, 41-49.

Piatkowski, U., Allcock, L., \& Vecchione, M., 2003. Cephalopod diversity and ecology. In: Fütterer, D.K., Brandt, A., Poore, G.C.B. (eds.). The expedition ANTARKTIS-XIX/3-4 of the research vessel Polarstern in 2002. Berichte zur Polarforschung (Reports on Polar Research) 470, 32-38. 
Pierce, G.J., Stowasser, G., Hastie, L.C., Bustamante, P., 2008. Geographic, seasonal and ontogenetic variation in cadmium and mercury concentrations in squid (Cephalopoda: Teuthoidea) from UK waters. Ecotoxicology and Environmental Safety 70, 422-432. https://doi.org/10.1016/j.ecoenv.2007.07.007

Potapowicz, J., Szumińska, D., Szopińska, M., Polkowska, Ż., 2019. The influence of global climate change on the environmental fate of anthropogenic pollution released from the permafrost: part I. Case study of Antarctica. Science of the Total Environment, 651, $1534-1548$.

R Core Team (2017). R: A Language and Environment for Statistical Computing. R Found. Stat. Comput., Vienna, Austria. http://www.R-project.org

Raimundo, J., Costa, P.M., Vale, C., Costa, M.H., Moura, I. (2010). Metallothioneins and trace elements in digestive gland, gills, kidney and gonads of Octopus vulgaris. Comparative Biochemistry and Physiology Part C: Toxicology \& Pharmacology 152(2), 139-146.

Rainbow, P.S., 1997. Trace metal accumulation in marine invertebrates: marine biology or marine chemistry? Journal of the Marine Biological Association of the United Kingdom, 77(1), 195-210.

Ratnasingham, S., Hebert, P.D., 2007. BOLD: The Barcode of Life Data System (http://www. barcodinglife. org). Molecular Ecology Notes, 7, 355-364.

Richert, J. E., Galván-Magaña, F., Klimley, A. P. (2015). Interpreting nitrogen stable isotopes in the study of migratory fishes in marine ecosystems. Marine Biology, 162(5), 10991110.

Rjeibi, M., Metian, M., Hajji, T., Guyot, T., Chaouacha-Chékir, R.B., Bustamante, P., 2014. Interspecific and geographical variations of trace metal concentrations in cephalopods from Tunisian waters. Environmental Monitoring and Assessment, 186, 3767-3783.

Rodhouse, P.G., Arnbom, T.R., Fedak, M.A., Yeatman, J., Murray, A.W.A., 1992. Cephalopod prey of the southern elephant seal, Mirounga leonina L. Canadian Journal of Zoology 70, 1007-1015.

Rosman, K.J.R., Chisholm, W., Boutron, C.F., Candelone, J.-P., Patterson, C.C., 1994. Anthropogenic lead isotopes in Antarctica. Geophysical Research Letters 21, 26692672.

Sanders, J.G., 1980. Arsenic cycling in marine systems. Marine Environmental Research, 3(4), $257-266$.

Schwarz, R., Hoving, H.J.T, Noever, C., Piatkowski, U., 2019. Life histories of Antarctic incirrate octopods (Cephalopoda: Octopoda). PloS One, 14(7). 
Seco, J., Xavier, J.C., Brierley, A.S., Bustamante, P., Coelho, J.P., Gregory, S., Fielding, S., Pardal, M.A., Pereira, B., Stowasser, G., Tarling, G.A., 2020. Mercury levels in Southern Ocean squid: Variability over the last decade. Chemosphere, 239, 124785.

Seixas, S., Bustamante, P., Pierce, G., 2005. Accumulation of mercury in the tissues of the common octopus Octopus vulgaris (L.) in two localities on the Portuguese coast. Science of The Total Environment 340, 113-122. https://doi.org/10.1016/j.scitotenv.2004.08.012

Shen, S., Li, X.F., Cullen, W.R., Weinfeld, M., Le, X.C., 2013. Arsenic binding to proteins. Chemical Reviews, 113(10), 7769-7792.

Storelli, M.M., Marcotrigiano, G.O., 2004. Content of mercury and cadmium in fish (Thunnus alalunga) and cephalopods (Eledone moschata) from the south-eastern Mediterranean Sea. Food Additives and Contaminants 21, 1051-1056. https://doi.org/10.1080/02652030400023127.

Strugnell, J.M., Allcock, A.L., Watts, P.C., 2017. Closely related octopus species show different spatial genetic structures in response to the Antarctic seascape. Ecology and evolution, 7(19), 8087-8099.

Sun, L., Xie, Z., 2001. Changes in lead concentration in Antarctic penguin droppings during the past 3,000 years. Environmental Geology 40, 1205-1208.

Szefer, P., Szefer, K., Pempkowiak, J., Skwarzec, B., Bojanowski, R., Holm, E., 1994. Distribution and coassociations of selected metals in seals of the Antarctic. Environmental Pollution 83, 341-349.

Taylor, V., Goodale, B., Raab, A., Schwerdtle, T., Reimer, K., Conklin, S., Karagas, M.R., Francesconi, K.A., 2017. Human exposure to organic arsenic species from seafood. Science of the Total Environment 580, 266-282.

Trevizani, T.H., Petti, M.A.V., Ribeiro, A.P., Corbisier, T.N., Figueira, R.C.L., 2018. Heavy metal concentrations in the benthic trophic web of Martel Inlet, Admiralty Bay (King George Island, Antarctica). Marine Pollution Bulletin 130, 198-205.

Tu, N.P.C., Agusa, T., Ha, N.N., Tuyen, B.C., Tanabe, S., Takeuchi, I., 2011. Stable isotopeguided analysis of biomagnification profiles of arsenic species in a tropical mangrove ecosystem. Marine Pollution Bulletin 63, 124-134.

Xavier, J., Rodhouse, P., Purves, M., Daw, T., Arata, J., Pilling, G., 2002. Distribution of cephalopods recorded in the diet of the Patagonian toothfish (Dissostichus eleginoides) around South Georgia. Polar Biology 25, 323-330. 
Xavier, J.C., Croxall, J.P., 2007. Predator-prey interactions: why do larger albatrosses eat bigger squid? Journal of Zoology 271, 408-417.

Xavier, J.C., Cherel, Y., Allcock, L., Rosa, R., Sabirov, R.M., Blicher, M.E., Golikov, A.V., 2018. A review on the biodiversity, distribution and trophic role of cephalopods in the Arctic and Antarctic marine ecosystems under a changing ocean. Marine Biology, 165(5), 93.

Zauke, G.P., Savinov, V.M., Ritterhoff, J., Savinova, T., 1999. Heavy metals in fish from the Barents Sea (summer 1994). Science of the Total Environment, 227(2-3), 161-173. 
Table 1. Specimen data for the eight octopod species included in this study. Acronyms are defined as follows: sample size $(n)$, mean \pm standard deviation (SD), mantle length (ML; mm), of the total length (TL; mm), and number of sex indetermined (Juvenile, J), female ( + ) and male ( $)^{)}$ specimen.

\begin{tabular}{|c|c|c|c|c|c|c|c|c|c|}
\hline \multirow{2}{*}{ Species } & Sampling & \multirow{2}{*}{$n$} & ML & ML & TL & TL & \multirow{2}{*}{$\mathrm{J}$} & \multirow{2}{*}{ q } & \multirow{2}{*}{$\sigma^{\lambda}$} \\
\hline & Depth (m) & & Mean \pm SD & $\min -\max$ & Mean \pm SD & $\min -\max$ & & & \\
\hline Adelieledone polymorpha & $293-323$ & 15 & $75.1 \pm 16.9$ & $50-109$ & $175.1 \pm 43.9$ & $110-265$ & & 7 & 8 \\
\hline Pareledone aequipapillae & $295-320$ & 4 & $38.5 \pm 4.3$ & $33-44$ & $86.8 \pm 19.1$ & $67-110$ & 2 & 2 & \\
\hline Pareledone albimaculata & $295-320$ & 5 & $45.4 \pm 21.1$ & $24-82$ & $101.6 \pm 21.7$ & $70-128$ & & 4 & 1 \\
\hline Pareledone aurata & $150-178$ & 7 & $58.4 \pm 26.2$ & $28-100$ & $142.4 \pm 43.4$ & $84-213$ & & 4 & 3 \\
\hline Pareledone charcoti & $109-118$ & 22 & $49.3 \pm 7.7$ & $35-63$ & $112.7 \pm 13.1$ & $89-145$ & & 11 & 11 \\
\hline Pareledone cornuta & $288-307$ & 4 & $46.2 \pm 6.3$ & $38-54$ & $104.0 \pm 18.1$ & $80-127$ & 1 & & 3 \\
\hline Pareledone felix & 288-307 & 2 & $49.5 \pm 17.9$ & $34-65$ & $125.0 \pm 63.5$ & $70-180$ & 1 & 1 & \\
\hline Pareledone turqueti & $288-307$ & 1 & 46 & & 112 & & & 1 & \\
\hline
\end{tabular}


Table 2. Analysis of covariance (ANCOVA) for the linear models fitted to the $\delta^{13} \mathrm{C}$ and $\delta^{15} \mathrm{~N}$ values of the mantle tissue from the different species used in this study. Abbreviations are defined as follows: $\mathrm{TL}=$ total length, $\mathrm{Df}=$ degrees of freedom, and 'depth' the sampling depth. Df - degrees of freedom. Asterisks indicate the level of significance: $*=p<0.05 ; * *=p<0.01$; and $* * *=p<0.001$.

\begin{tabular}{|c|c|c|c|c|c|}
\hline & Df & Sum of squares & Mean square & F value & Significance \\
\hline \multicolumn{6}{|c|}{$\delta^{13} \mathrm{C}$} \\
\hline Depth & 1 & 18.22 & 18.22 & 61.55 & $* * *$ \\
\hline Species & 8 & 42.52 & 5.31 & 20.72 & $* * *$ \\
\hline Size (TL) & 1 & 0.16 & 0.16 & 0.63 & \\
\hline Sex & 2 & 1.89 & 0.94 & 3.68 & $*$ \\
\hline$\delta^{15} \mathrm{~N}$ & 1 & 2.39 & 2.38 & 9.30 & $* *$ \\
\hline Residuals & 47 & 12.05 & 0.26 & & \\
\hline \multicolumn{6}{|c|}{$\delta^{15} \mathrm{~N}$} \\
\hline Depth & 1 & 45.33 & 45.33 & 372 & $* * *$ \\
\hline Species & 8 & 52.02 & 6.50 & 53.72 & $* * *$ \\
\hline Size (TL) & 1 & 0.11 & 0.11 & 0.93 & \\
\hline Sex & 2 & 0.02 & 0.01 & 0.09 & \\
\hline$\delta^{13} \mathrm{C}$ & 1 & 1.16 & 1.16 & 9.56 & $* *$ \\
\hline Residuals & 47 & 5.69 & 0.12 & & \\
\hline
\end{tabular}


Table 3. Output of the generalised linear models (GLMs) for variables that significantly influence the trace element concentrations of the analysed octopod species. Species included were: A. polymorpha, P. aequipapillae, P. albimaculata, P. aurata, P. charcoti, and P. cornuta. The $p$-values of the variables are shown according to likelihood ratio tests $(* * * 0.001, * * 0.01$, $* 0.05)$. Negative $(\downarrow)$ and positive $(\uparrow)$ effects for the continuous variable size (total length [TL]) are indicated with arrows $(\uparrow \uparrow \uparrow=0.001, \uparrow \uparrow=0.01, \uparrow=0.05)$. For $\mathrm{Cd}$, tissue type was not included in the GLM because it was not analysed (NA). Models for each element included $\delta^{15} \mathrm{~N}$ and the residuals (Resid) of $\delta^{13} \mathrm{C}$.

\begin{tabular}{|c|c|c|c|c|c|c|c|c|c|c|c|c|c|}
\hline & $\mathrm{Ag}$ & As & $\mathrm{Cd}$ & $\mathrm{Co}$ & $\mathrm{Cr}$ & $\mathrm{Cu}$ & $\mathrm{Fe}$ & $\mathrm{Hg}$ & $\mathrm{Ni}$ & $\mathrm{Pb}$ & $\mathrm{Se}$ & V & $\mathrm{Zn}$ \\
\hline Tissue type & $* * *$ & $* * *$ & NA & $* * *$ & $*$ & $* * *$ & $* * *$ & & $* * *$ & $* * *$ & $* * *$ & $* * *$ & $* * *$ \\
\hline Species & & $* * *$ & $* * *$ & $* *$ & & & $*$ & & $* * *$ & & $* *$ & $* * *$ & $* * *$ \\
\hline Depth & & $* * *$ & & $* * *$ & & & $* * *$ & & $* * *$ & $* *$ & $* * *$ & $*$ & \\
\hline Size (TL) & & & & & & $\downarrow \downarrow \downarrow$ & & & & & $\uparrow$ & & $\downarrow$ \\
\hline Sex & & & $* * *$ & $* * *$ & & $* *$ & $*$ & & & $*$ & & & \\
\hline$\delta^{15} \mathrm{~N}$ & $\uparrow$ & $\uparrow \uparrow \uparrow$ & $\downarrow$ & & & & & & & & $\uparrow$ & & \\
\hline \multicolumn{14}{|l|}{$\operatorname{Resid}\left(\delta^{13} C\right)$} \\
\hline Species x TL & & $* *$ & & $*$ & & & & & & & & & \\
\hline
\end{tabular}


Table 4. Concentrations of $\mathrm{Cd}$ in the digestive gland and $\mathrm{Hg}$ (mean \pm standard deviation [SD]) in muscular tissues of octopods from temperate and (sub-)Antarctic areas. All concentrations are presented in $\mu \mathrm{g} \mathrm{g}-1 \mathrm{dw}$. Abbreviations as followed: $\left({ }^{\mathrm{A}}\right)=\operatorname{arm}$ muscles and $\left({ }^{\mathrm{M}}\right)=$ mantle muscles. Converted values from wet weight are indicated with *. 'Year' indicates the tissue collection date.

\begin{tabular}{|c|c|c|c|c|c|}
\hline Species & $\begin{array}{l}\text { Cd in the digestive gland } \\
\text { Mean } \pm \text { SD }\end{array}$ & $\begin{array}{l}\mathrm{Hg} \text { in the muscle } \\
\text { Mean } \pm \mathrm{SD}\end{array}$ & Location & Year & Reference \\
\hline \multicolumn{6}{|c|}{ Antarctic species } \\
\hline \multicolumn{6}{|l|}{ Adelieledone } \\
\hline A. polymorpha & $112 \pm 44.4$ & $0.56 \pm 0.13^{\mathrm{M}}$ & Antarctic Peninsula & 2012 & This study \\
\hline A. polymorpha & & $0.322 \pm 0.088^{\mathrm{M}}$ & South Georgia coast & 2004 & Matias el al., 2019 \\
\hline A. polymorpha & & $0.126 \pm 0.032^{\mathrm{M}}$ & South Georgia region & 2004 & Matias et al., 2020 \\
\hline \multicolumn{6}{|l|}{ Benthoctopus } \\
\hline B. thielei & 215 & & Kerguelen Islands & 1995 & Bustamante et al., 1998b \\
\hline \multicolumn{6}{|l|}{ Graneledone } \\
\hline G. gonzalezi & 369 & & Kerguelen Islands & 1995 & Bustamante et al., 1998b \\
\hline \multicolumn{6}{|l|}{ Pareledone } \\
\hline P. aequipapillae & $80.92 \pm 23.02$ & $0.20 \pm 0.03^{\mathrm{M}}$ & Antarctic Peninsula & 2012 & This study \\
\hline P. albimaculata & $85.89 \pm 43.27$ & $0.15 \pm 0.02^{\mathrm{M}}$ & Antarctic Peninsula & 2012 & This study \\
\hline P. annata & $175 \pm 65.22$ & $0.13 \pm 0.03^{\mathrm{M}}$ & Antarctic Peninsula & 2012 & This study \\
\hline P. charcoti & $152 \pm 87.33$ & $0.41 \pm 0.22^{\mathrm{M}}$ & Antarctic Peninsula & 2012 & This study \\
\hline P. cornuta & $112 \pm 11.98$ & $0.12 \pm 0.01^{\mathrm{M}}$ & Antarctic Peninsula & 2012 & This study \\
\hline P. felix & $76.4 \pm 1.76$ & $0.39 \pm 0.03^{\mathrm{M}}$ & Antarctic Peninsula & 2012 & This study \\
\hline P. subtilis & $164 \pm 140$ & $0.19 \pm 0.04^{\mathrm{M}}$ & Antarctic Peninsula & 2012 & This study \\
\hline P. turqueti & 204 & $0.28^{\mathrm{M}}$ & Antarctic Peninsula & 2012 & This study \\
\hline P. turqueti & & $0.434 \pm 0.128^{\mathrm{M}}$ & South Georgia Coast & 2004 & Matias el al., 2019 \\
\hline
\end{tabular}




\begin{tabular}{|c|c|c|c|c|c|}
\hline \multicolumn{2}{|c|}{ P. turqueti } & $0.196 \pm 0.083^{\mathrm{M}}$ & South Georgia region & 2004 & Matias et al., 2020 \\
\hline \multicolumn{6}{|c|}{ Temperate species } \\
\hline \multicolumn{6}{|l|}{ Eledone } \\
\hline E. cirrhosa & $79.87 \pm 4.38^{*}$ & & Cotentin Coast, English Channel & 1987 & Miramand and Bentley, 1992 \\
\hline E. cirrhosa & $16.3 \pm 9.6$ & $0.34 \pm 0.072^{\mathrm{M}}$ & Bay of Biscay & $2005-2008$ & Chouvelon et al., 2011 \\
\hline E. cirrhosa & & $6.06^{\mathrm{M}}$ & Tyrrhenian Sea & 1999 & Barghigiani et al., 2000 \\
\hline E. cirrhosa & $2333 \pm 1000^{*}$ & $0.144 \pm 0.071^{\mathrm{M}}$ & Faroe Islands & 1997 & Bustamante et al. 1998a, 2006 \\
\hline \multicolumn{6}{|l|}{ Octopus } \\
\hline O. vulgaris & $50 \pm 10$ & & Monaco, Mediterranean Sea & 1980 & Miramand and Guary, 1980 \\
\hline O. vulgaris & $94-185$ & & Matosinhos, Portugal & 2002 & Raimundo et al., 2008 \\
\hline O. vulgaris & $136-269$ & & Northwest Coast, Portugal & 2001 & Raimundo et al., 2005 \\
\hline O. vulgaris & $20-122$ & & South Coast, Portugal & 2001 & Raimundo et al., 2005 \\
\hline \multirow[t]{3}{*}{ O. vulgaris } & $65.8 \pm 24.2$ & $0.13 \pm 0.02^{\mathrm{M}}$ & Sfax, Tunisia & 2010 & Rjeibi et al. 2014 \\
\hline & $42.5 \pm 20.3$ & $0.18 \pm 0.06^{\mathrm{M}}$ & Bizerte, Tunisia & & \\
\hline & $31.0 \pm 9.2$ & $0.13 \pm 0.06^{\mathrm{M}}$ & Monastir, Tunisia & & \\
\hline O. vulgaris & & $0.43 \pm 0.13^{\mathrm{A}}$ & Cascais, Portugal & $2002-2003$ & Seixas et al., 2005 \\
\hline O. vulgaris & & $0.213 \pm 0.02 * \mathrm{M}$ & Azores & $1990-1991$ & Monteiro et al., 1992 \\
\hline
\end{tabular}




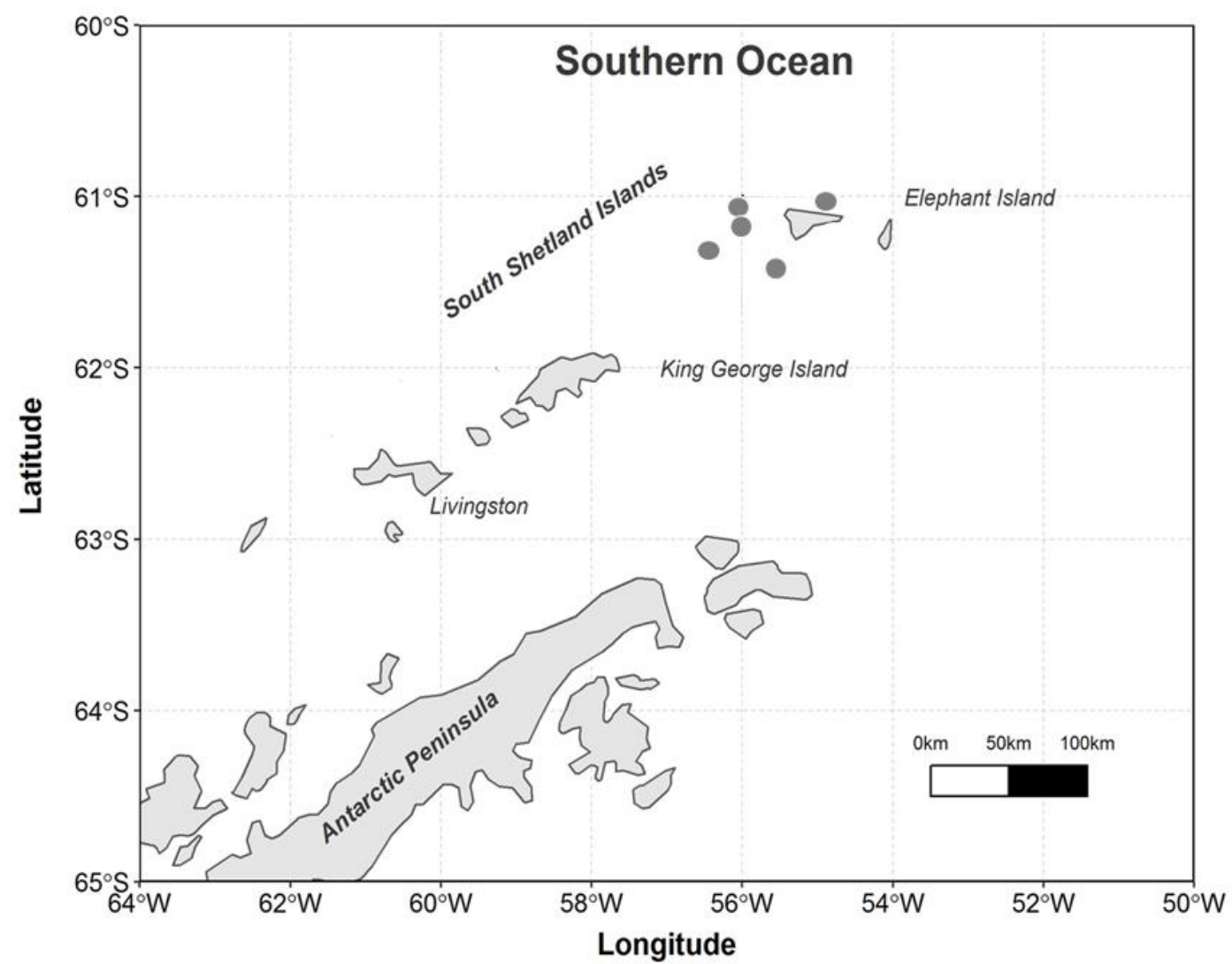

Figure 1. Sampling locality of the specimen used in this study (grey circles), adapted from Schwarz et al., 2019. 


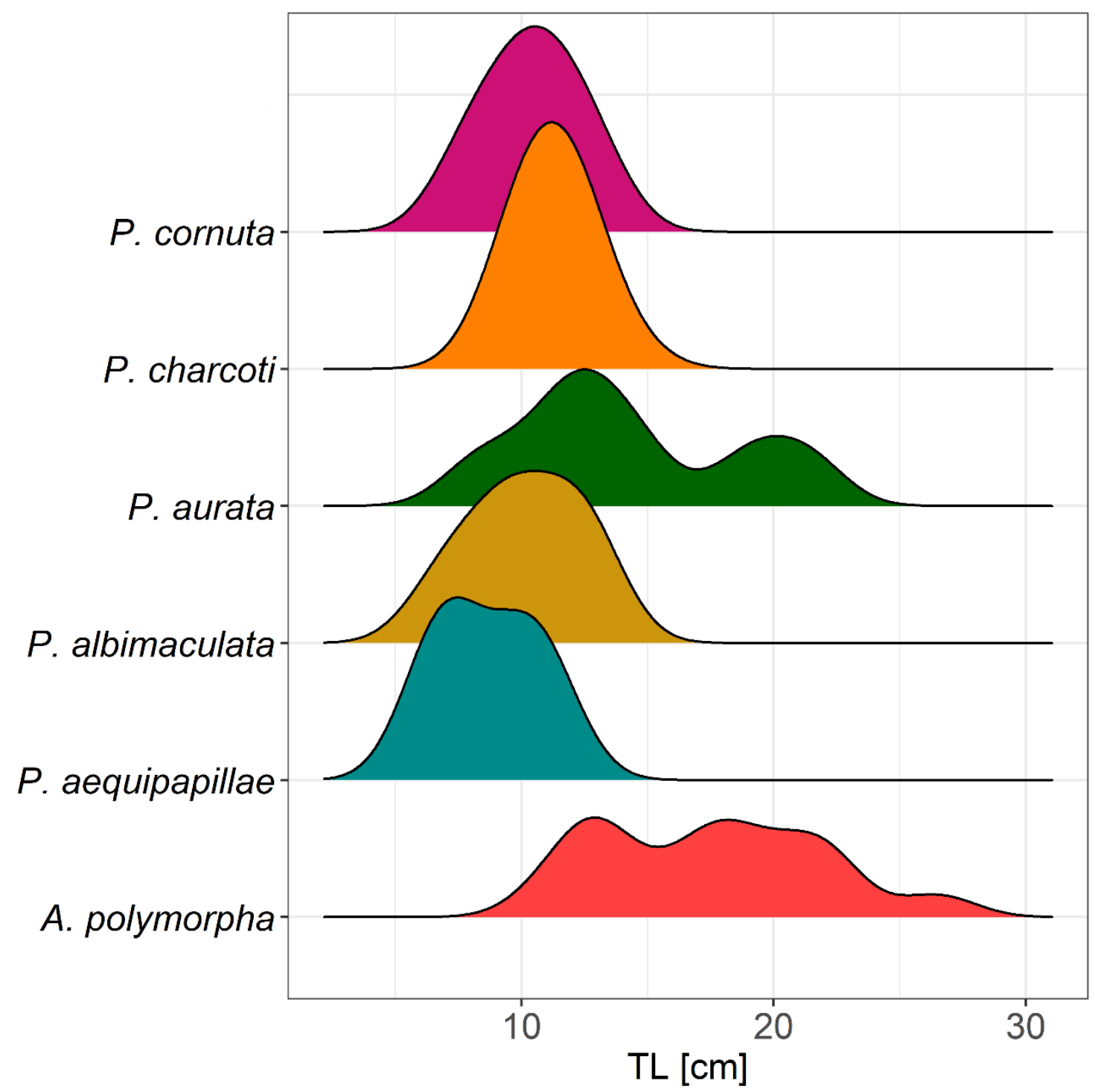

Figure 2. Frequencies of sizes for the analysed octopod specimens analysed in our study (only including species with $n>3$ ) from near Elephant Island, Antarctic Ocean. 


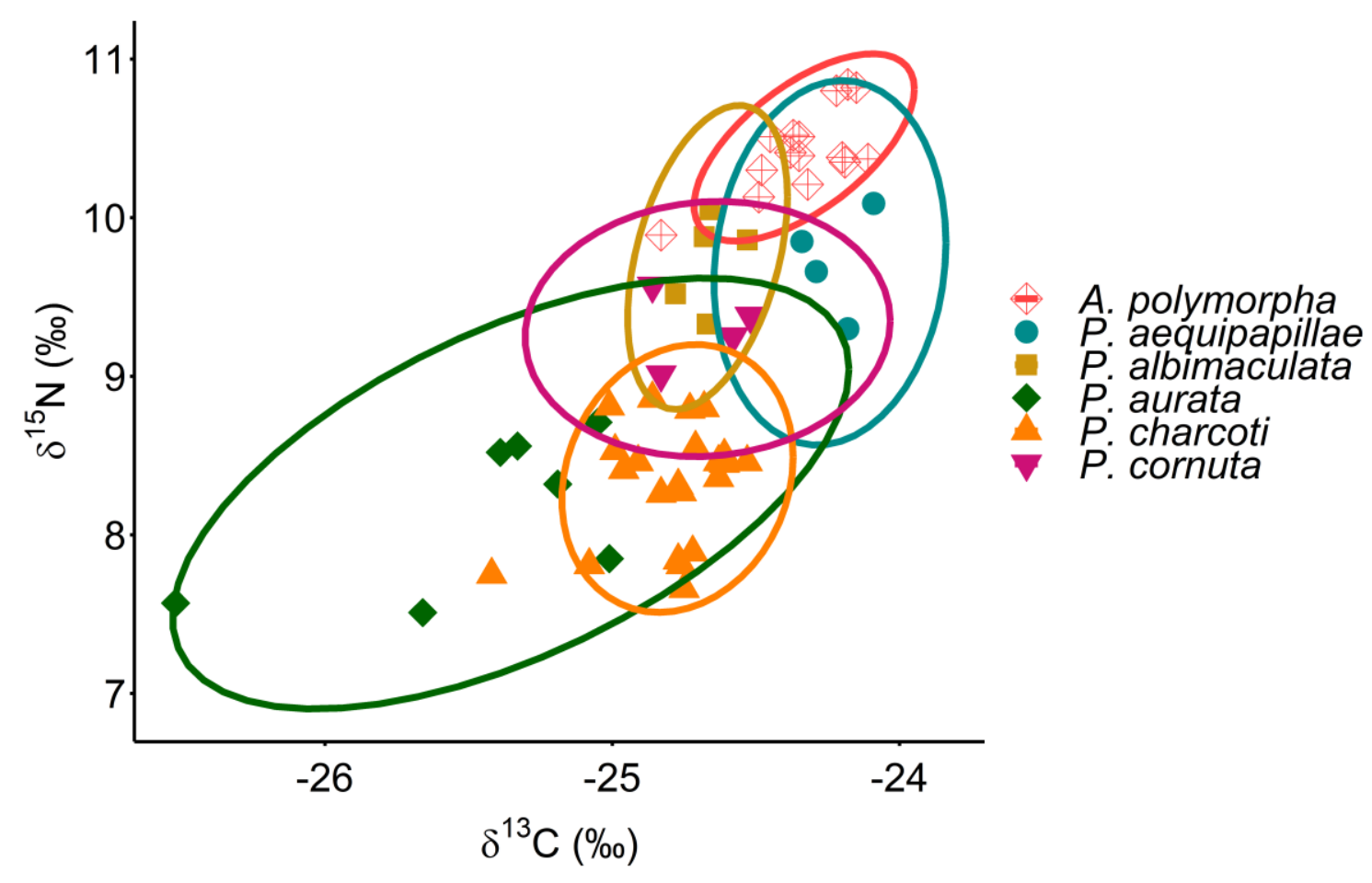

Figure 3. Carbon $\left(\delta^{13} \mathrm{C}\right)$ and nitrogen $\left(\delta^{15} \mathrm{~N}\right)$ stable isotope values (\%o) in eight octopods species from the genera Adelieledone and Pareledone collected from near Elephant Island, Antarctic Ocean. Ellipses indicate the $95 \%$ confidence interval around the species groupings. 


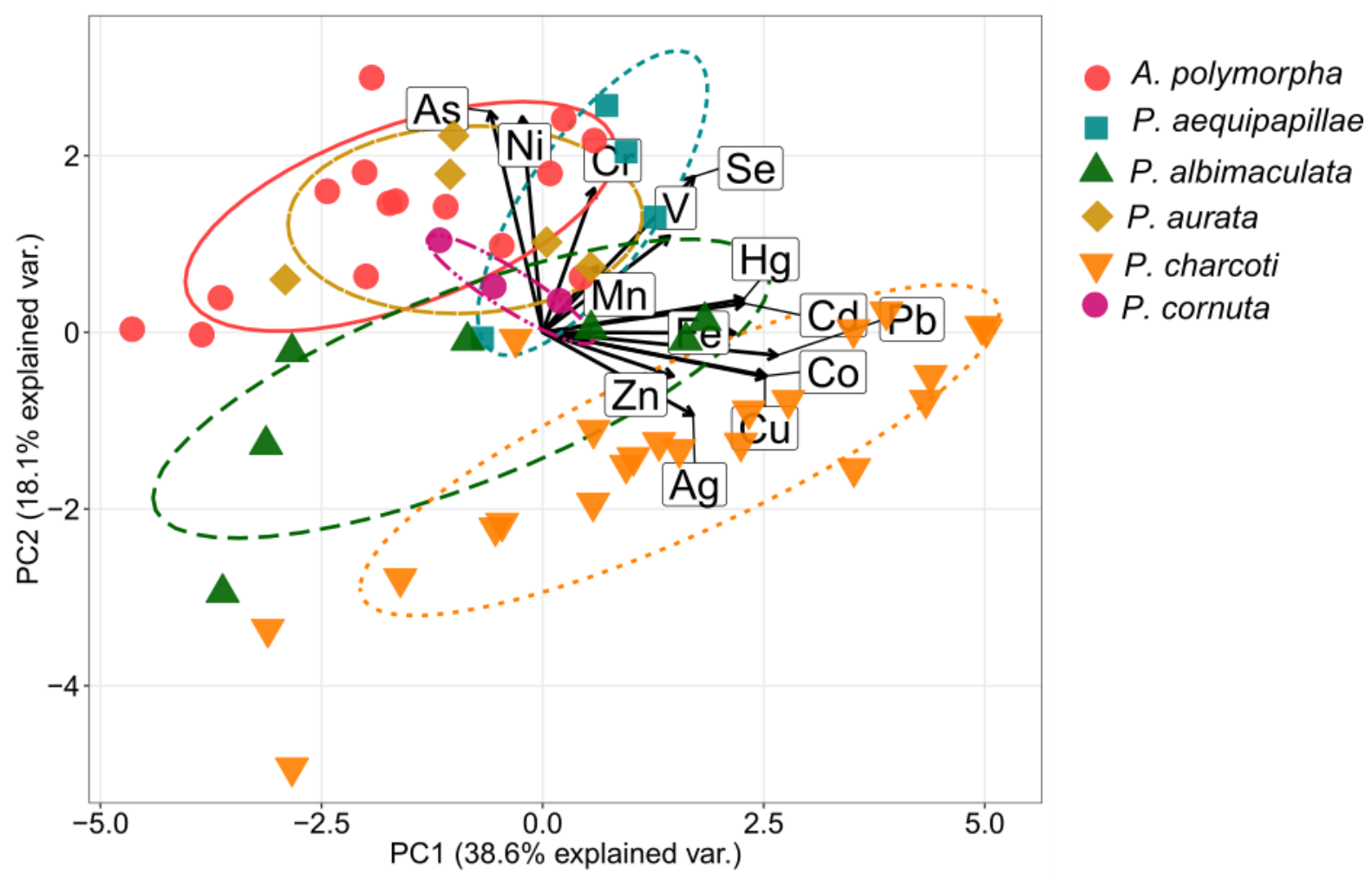

Figure 4. Principal component analysis (PCA) of the digestive gland trace element concentrations of six octopods species from the genera Adelieledone and Pareledone collected near Elephant Island, Antarctic Ocean. Due to the low sampling number, P. felix and P. turqueti were excluded from the PCA. 


\section{Supplementary Material}

Table S1. Trace-element concentrations and stable isotope values in the digestive gland and mantle tissue ( $\mu \mathrm{g} \mathrm{g}^{-1} \mathrm{dw}$ ) of the eight octopod species analysed in this study, collected from near Elephant Island, Antarctic Ocean. Data is provided for the mean, standard deviation (SD), and minimum $(\min )$ and maximum $(\max )$ concentrations. $\mathrm{NA}=$ data not analysed.

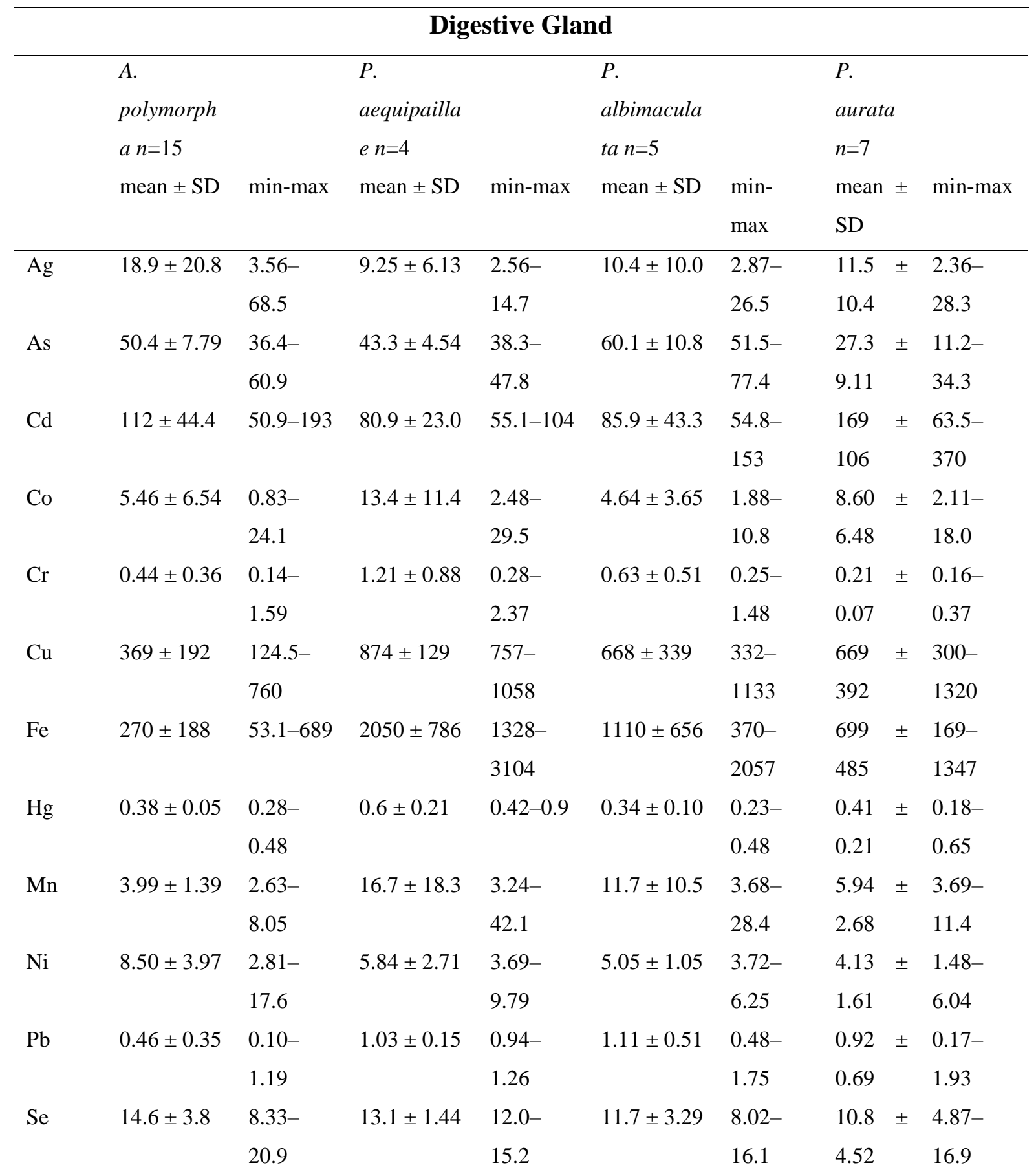




$\begin{array}{llllllllll}\mathrm{V} & 35.2 \pm 22.1 & 8.63- & 24.7 \pm 4.35 & 19.2- & 56.7 \pm 53.4 & 14.0- & 14.3 & \pm 1.63- \\ & & 94.3 & & 29.8 & & 131 & 12.3 & 32.0 \\ \mathrm{Zn} & 251 \pm 69.2 & 153-404 & 189 \pm 44.8 & 141-247 & 187 \pm 28.3 & 146-219 & 175 & \pm & 103-299 \\ & & & & & & & & \end{array}$

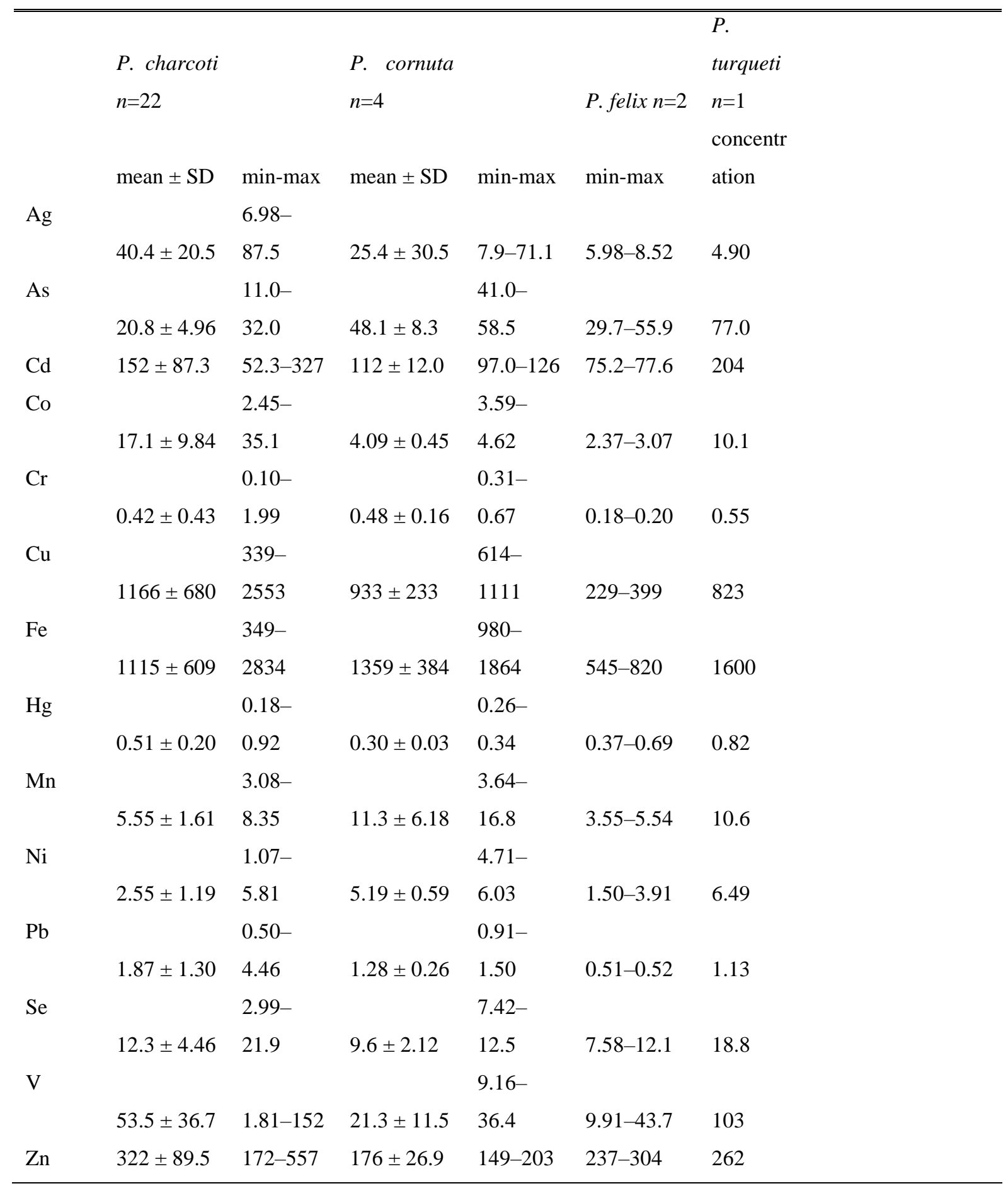

\section{Mantle}

\begin{tabular}{clll}
\hline Mantle & A. polymorpha $n=15$ & $P$. aequipaillae & $P$. \\
& & $n=4$ & albimaculata \\
mean \pm sd & & $n=5$ & min-max \\
min-max & mean \pm sd & mean \pm min-max \\
\hline
\end{tabular}




\begin{tabular}{|c|c|c|c|c|c|c|}
\hline$\delta^{13} \mathrm{C}$ & $-24.34 \pm 0.18$ & $-24.83-(-24.11)$ & $-24.23 \pm 0.11$ & $-24.34-(-24.09)$ & $-24.66 \pm 0.09$ & $-24.78-(-24.53)$ \\
\hline$\delta^{15} \mathrm{~N}$ & $10.34 \pm 0.26$ & $9.89-10.84$ & $9.72 \pm 0.33$ & $9.30-10.09$ & $9.73 \pm 0.29$ & $9.33-10.05$ \\
\hline $\mathrm{Ag}$ & NA & NA & $3.04 \pm 0.90$ & $2.04-4.15$ & $1.76 \pm 0.92$ & $0.75-2.95$ \\
\hline As & $65.4 \pm 10.9$ & $47.2-89.7$ & $52.9 \pm 4.34$ & $47.9-58.1$ & $72.3 \pm 10.7$ & $58.4-84.2$ \\
\hline $\mathrm{Cd}$ & NA & NA & NA & NA & NA & NA \\
\hline Co & $0.90 \pm 0.48$ & $0.31-2.23$ & $1.58 \pm 0.93$ & $1.07-2.97$ & $0.54 \pm 0.12$ & $0.44-0.72$ \\
\hline $\mathrm{Cr}$ & $0.20 \pm 0.07$ & $0.11-0.36$ & $0.50 \pm 0.52$ & $0.13-1.26$ & $0.16 \pm 0.03$ & $0.13-0.21$ \\
\hline $\mathrm{Cu}$ & $107 \pm 95.4$ & $40.5-403$ & $129 \pm 23.5$ & $109-161$ & $77.4 \pm 44.7$ & $33.5-152.3$ \\
\hline $\mathrm{Fe}$ & $79.6 \pm 91.4$ & $20.86-362$ & $27.1 \pm 10.6$ & $16.0-37.3$ & $22.7 \pm 22.8$ & $5.63-61.5$ \\
\hline $\mathrm{Hg}$ & $0.56 \pm 0.13$ & $0.40-0.76$ & $0.20 \pm 0.03$ & $0.17-0.24$ & $0.15 \pm 0.02$ & $0.13-0.19$ \\
\hline $\mathrm{Mn}$ & $3.27 \pm 1.35$ & $2.13-7.82$ & $2.06 \pm 0.34$ & $1.63-2.39$ & $2.14 \pm 0.52$ & $1.5-2.76$ \\
\hline $\mathrm{Ni}$ & $4.06 \pm 1.44$ & $1.75-7.21$ & $2.05 \pm 0.74$ & $1.20-2.76$ & $1.41 \pm 0.33$ & $1.02-1.81$ \\
\hline $\mathrm{Pb}$ & $0.09 \pm 0.04$ & $0.05-0.17$ & $0.07 \pm 0.01$ & $0.06-0.08$ & $0.12 \pm 0.04$ & $0.09-0.18$ \\
\hline $\mathrm{Se}$ & $7.09 \pm 2.02$ & $3.54-11.2$ & $5.45 \pm 0.97$ & $4.13-6.42$ & $4.45 \pm 0.06$ & $4.36-4.51$ \\
\hline $\mathrm{V}$ & $7.65 \pm 4.31$ & $3.45-18.7$ & $3.73 \pm 2.67$ & $1.40-7.45$ & $5.90 \pm 6.39$ & $1.28-16.4$ \\
\hline \multirow[t]{2}{*}{$\mathrm{Zn}$} & $151 \pm 41.2$ & $103-244$ & $89.5 \pm 7.34$ & $84.0-99.7$ & $91.2 \pm 12.4$ & $78.7-111$ \\
\hline & $\begin{array}{l}P . \text { charcoti } n=22 \\
\text { mean } \pm \text { sd }\end{array}$ & $\min -\max$ & $\begin{array}{l}\text {. cornuta } n=4 \\
\text { mean } \pm \text { sd }\end{array}$ & $\min -\max$ & $\begin{array}{l}P . \text { felix } n=2 \\
\min -\max \end{array}$ & $\begin{array}{l}\text { P. turqueti } n=1 \\
\text { concentration }\end{array}$ \\
\hline$\delta^{13} \mathrm{C}$ & $-24.81 \pm 0.20$ & $-25.42-(-24.53)$ & $-24.70 \pm 0.17$ & $-24.86-(-24.52)$ & $-24.89-(-23.97)$ & -24.11 \\
\hline$\delta^{15} \mathrm{~N}$ & $8.32 \pm 0.37$ & $7.66-8.86$ & $9.3 \pm 0.24$ & $9.01-9.57$ & $9.78-10.03$ & 9.87 \\
\hline $\mathrm{Ag}$ & $0.29 \pm 0.42$ & $0.04-1.66$ & $1.09 \pm 0.64$ & $0.51-1.78$ & $2.2-6.29$ & 2.19 \\
\hline As & $22.1 \pm 4.64$ & $15.4-30.9$ & $66.4 \pm 8.23$ & $60.5-78.6$ & $51.0-55.3$ & 97.9 \\
\hline $\mathrm{Cd}$ & NA. & NA. & NA. & NA. & NA. & NA. \\
\hline Co & $0.27 \pm 0.25$ & $0.05-1.15$ & $0.37 \pm 0.09$ & $0.27-0.49$ & $1.43-1.64$ & 1.66 \\
\hline $\mathrm{Cr}$ & $0.24 \pm 0.23$ & $0.11-1.15$ & $0.14 \pm 0.04$ & $0.11-0.19$ & $0.12-0.22$ & 0.15 \\
\hline $\mathrm{Cu}$ & $33.5 \pm 21.2$ & $15.9-98.7$ & $53.1 \pm 22.5$ & $34.7-82.9$ & $73.7-202$ & 134 \\
\hline $\mathrm{Fe}$ & $9.36 \pm 6.79$ & $5.51-39.0$ & $29.6 \pm 20.2$ & $7.80-52.9$ & $26.8-131$ & 30.6 \\
\hline $\mathrm{Hg}$ & $0.41 \pm 0.22$ & $0.15-1.13$ & $0.12 \pm 0.01$ & $0.12-0.13$ & $0.37-0.41$ & 0.28 \\
\hline $\mathrm{Mn}$ & $3.63 \pm 1.83$ & $1.43-7.48$ & $2.67 \pm 0.88$ & $1.98-3.95$ & $1.66-2.52$ & 3.29 \\
\hline $\mathrm{Ni}$ & $0.52 \pm 0.14$ & $0.30-0.76$ & $0.86 \pm 0.12$ & $0.78-1.04$ & $0.97-2.26$ & 2.63 \\
\hline $\mathrm{Pb}$ & $0.05 \pm 0.03$ & $0.03-0.15$ & $0.10 \pm 0.01$ & $0.09-0.11$ & $0.06-0.13$ & 0.15 \\
\hline $\mathrm{Se}$ & $2.34 \pm 0.40$ & $1.84-3.42$ & $2.90 \pm 0.54$ & $2.57-3.70$ & $5.97-7.64$ & 6.61 \\
\hline $\mathrm{V}$ & $1.66 \pm 0.53$ & $0.91-2.77$ & $1.43 \pm 0.37$ & $1.12-1.95$ & $6.95-16.0$ & 21.2 \\
\hline $\mathrm{Zn}$ & $99.9 \pm 16.8$ & $72.1-136$ & $96.2 \pm 16.5$ & $76.1-112.1$ & $125-154.7$ & 106 \\
\hline
\end{tabular}


Table S2. Analysis of covariance (ANCOVA) for the linear models fitted to the trace element concentrations of Pareledone charcoti. Asterisks indicate the level of significance: $*=p<0.05 ; * *=$ $\mathrm{p}<0.01$; and $* * *=\mathrm{p}<0.001$. NA $=$ not analysed. The following variables were analysed: size (total length; TL); depth (sampling depth), $\delta^{15} \mathrm{~N}$ (nitrogen stable isotope ratio); and Resd $\left(\delta^{13} \mathrm{C}\right)$ (residuals of $\delta^{13} \mathrm{C}$ ). Negative $(\downarrow)$ and positive $(\uparrow)$ effects for the continuous variable size (total length [TL]) are indicated with arrows $(\uparrow \uparrow \uparrow=0.001, \uparrow \uparrow=0.01, \uparrow=0.05)$.

\begin{tabular}{|c|c|c|c|c|c|c|c|c|c|c|c|c|c|}
\hline & $\mathrm{Ag}$ & As & $\mathrm{Cd}$ & Co & $\mathrm{Cr}$ & $\mathrm{Cu}$ & $\mathrm{Fe}$ & $\mathrm{Hg}$ & $\mathrm{Ni}$ & $\mathrm{Pb}$ & $\mathrm{Se}$ & V & $\mathrm{Zn}$ \\
\hline $\begin{array}{l}\text { Tissu } \\
\mathrm{e}\end{array}$ & $* * *$ & & NA & $* * *$ & & $* * *$ & $* * *$ & & $* * *$ & $* * *$ & $* * *$ & $* * *$ & $* * *$ \\
\hline Sex & & & $* * *$ & $* * *$ & & $* *$ & $* *$ & & $* * *$ & $* * *$ & $* *$ & & $* * *$ \\
\hline Size & & & & & & & & & & & & & \\
\hline$\delta^{15} \mathrm{~N}$ & & & & & & & & $\uparrow$ & & & $\uparrow$ & & $\uparrow$ \\
\hline $\operatorname{Res} d($ & & & & & & & & & & & & & \\
\hline$\left.\delta^{13} \mathrm{C}\right)$ & & & & & & & & & & & & & \\
\hline
\end{tabular}




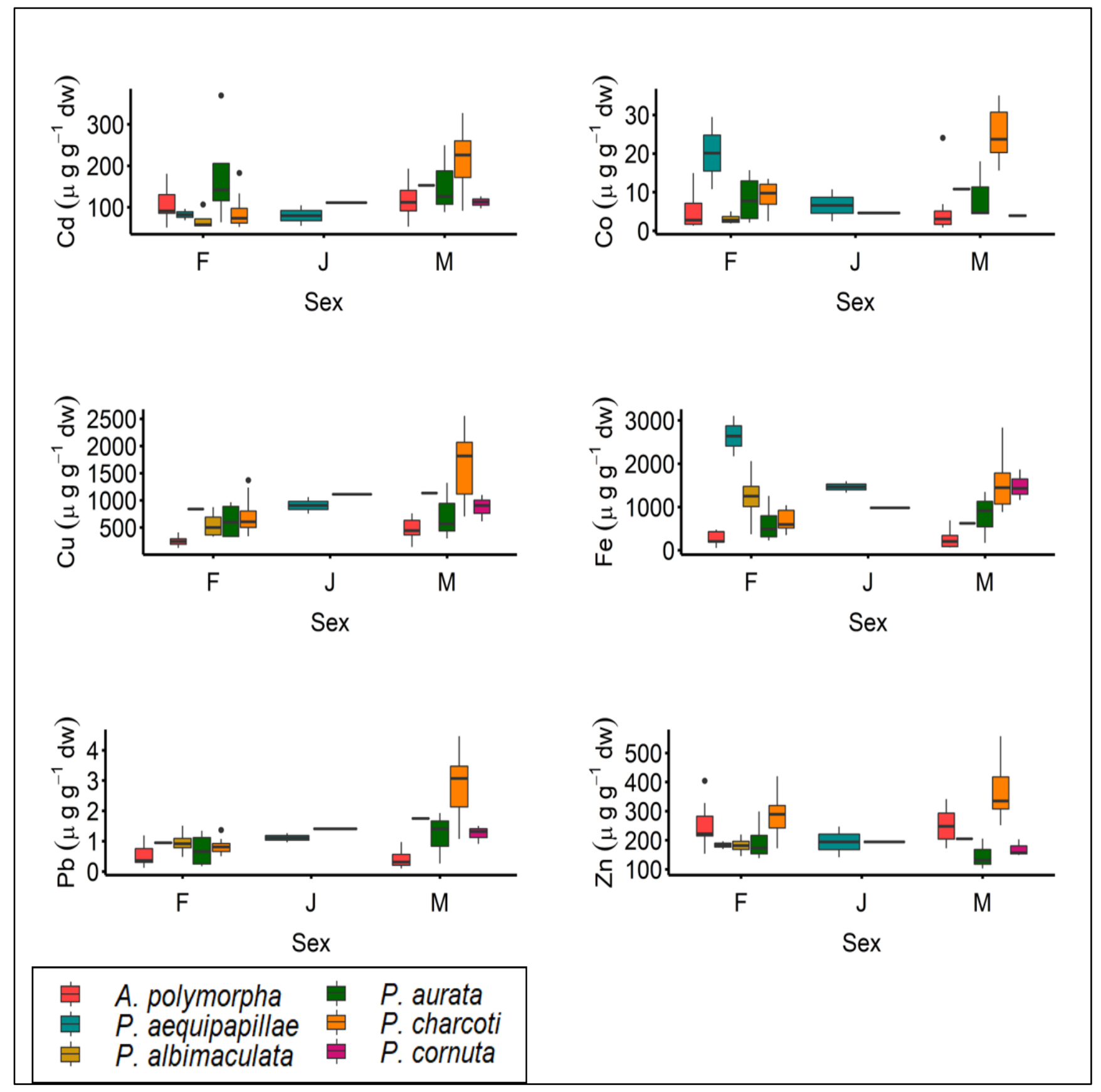

Figure S1. Digestive gland concentrations of trace elements $\left(\mu \mathrm{g} \mathrm{g}^{-1} \mathrm{dw}\right)$ between female $(\mathrm{F})$, sex indet./juvenile (J) and male (M) specimens of six octopod species in the genera Adelieledone and Pareledone from the Antarctic Ocean. Elements that had significant differences in the GLMs are included $(\mathrm{Cd}, \mathrm{Co}, \mathrm{Cu}, \mathrm{Fe}, \mathrm{Pb}$, and $\mathrm{Zn})$. Pareledone felix and P.turqueti were excluded from the GLMs due to their low sampling size. 


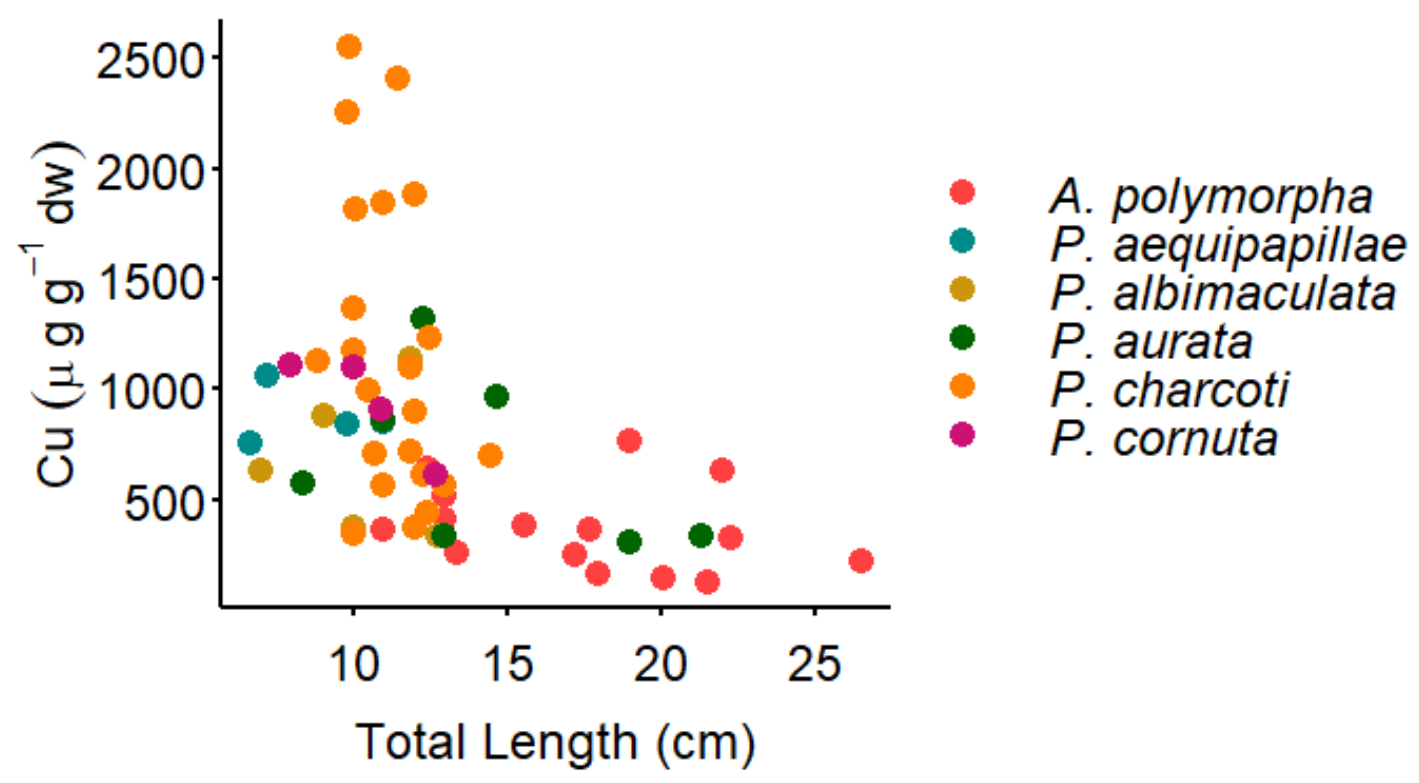

Figure S2. Digestive gland $\mathrm{Cu}$ concentrations $\left(\mu \mathrm{g} \mathrm{g}^{-1} \mathrm{dw}\right)$ of six octopod species in the genera Adelieledone and Pareledone, from the Antarctic Ocean in relation to size (total length; TL). Pareledone felix and P. turqueti were excluded from the GLMs due to their low sampling size. 